University of Florida Levin College of Law

UF Law Scholarship Repository

Faculty Publications

Faculty Scholarship

$10-1-2010$

\title{
The Inconvenience of a "Constitution [that] follows the flag ... but doesn't quite catch up with it": From Downes v. Bidwell to Boumediene v. Bush
}

Pedro A. Malavet

University of Florida Levin College of Law, malavet@law.ufl.edu

Follow this and additional works at: http://scholarship.law.ufl.edu/facultypub

Part of the Constitutional Law Commons, Legal History, Theory and Process Commons, and the Transnational Law Commons

\section{Recommended Citation}

Pedro A. Malavet, The Inconvenience of a "Constitution [that] follows the flag ... but doesn't quite catch up with it": From Downes v. Bidwell to Boumediene v. Bush, 80 Miss. L.J. 181 (2010), available at http://scholarship.law.ufl.edu/facultypub/311

This Article is brought to you for free and open access by the Faculty Scholarship at UF Law Scholarship Repository. It has been accepted for inclusion in Faculty Publications by an authorized administrator of UF Law Scholarship Repository. For more information, please contact outler@law.ufl.edu. 


\title{
THE INCONVENIENCE OF A "CONSTITUTION [THAT] FOLLOWS THE FLAG . . BUT DOESNT QUITE CATCH UP WITH IT": FROM DOWNES V. BIDWELL TO BOUMEDIENE V. BUSH
}

\author{
Pedro A. Malavet
}

INTRODUCTION

I. BOUMEDIENE V. BUSH: THE INSULAR CASES IN THE TWENTYFIRST CENTURY

II. SOCIAL, HISTORICAL, AND LEGAL CONTEXT: OUR

ISLANDS AND THEIR PEOPLE

III. PUERTO RICO IN 1901: SELF-GOVERNMENT AND SPANISH

CITIZENSHIP THAT DID NOT LAST LONG.

IV. THE UNITED STATES IN 1901: IN THE AFTERGLOW OF THE

SPANISH-AMERICAN WAR

V. MR. BIDWELL AND THE 576 BOXES OF ORANGES

1 The quote is the response of then Secretary of War Elihu Root when-after hearing a reading of the five opinions of the Supreme Court in the Downes case in May of 1901 - confused reporters asked how the justices had replied to the question, "Does the constitution follow the flag?" GEORGE SHIRAS, JUSTICE GEORGE SHIRAS, JR. OF PitTsburgh, Associate Justice of the United States SuPREme Court, 1892-1903: A CHRONICLe OF HIS FAMILY, LIFE, AND TIMES 191 (Winfield Shiras ed., Univ. of Pittsburgh Press 1953) (citing ARTHUR WaLlace DUNN, From HaRRISON to HaRding: A Personal NarRative, Covering A ThiRd OF A Century, 1888-1921, at 256-57 (1922)). As the title suggests, this article is a follow up to my book chapter "The Constitution Follows the Flag . . but Doesn't Quite Catch Up with It": The Story of Downes v. Bidwell, in RACE LAW STORIES 111 (Rachel F. Moran \& Devon W. Carbado eds., 2008) [hereinafter The Story of Downes]. The chapter and article also reflect the content of my book AMERICA's ColonY: THE Political AND CUltuRal CONFLiCT BETWEEN THE UNITED STATES AND PUERTo RICo (N.Y. Univ. Press 2004) [hereinafter AMERICA's COLONY].

- Professor of Law, the University of Florida Fredric G. Levin College of Law; J.D. and LL.M., Georgetown University Law Center. I am grateful to Dean Kevin R. Johnson for helpful comments on a draft of this article. I am grateful to my home institution for a summer research grant and sabbatical that I partially spent working on this piece. 
VI. THE DOWNES SUPREMACY: FROM IMPERIAL VACILLATION TO UNANIMOUS PLENARY POWER

VII. DOWNESS LEGACY: CITIZENSHIP OF A SECOND-CLASS...... 243 CONCLUSION: A DOWNES RULE FOR CITIZENS THAT THE BOUMEDIENE COURT REFUSES TO SEE

\section{INTRODUCTION}

Boumediene v. Bush, resolved by the Supreme Court in June of 2008, ruled that so-called "enemy combatants" held by the United States at Guantánamo Bay Naval Station have a constitutionally-guaranteed right to habeas corpus review of their detention by federal courts. ${ }^{2}$ In reaching this result, the majority opinion relied upon what it labeled the "doctrine" of the Insular Cases, ${ }^{3}$ a series of decisions arising mostly as a result of the Spanish-American War of 1898. While they disagreed on whether or not the rule should apply to Guantánamo, the dissenting justices and those in the majority unanimously agreed that the over-a-century-old rule of the Insular Casesthat in order to permit substantial discretion to the executive and legislative branches of government to deal with new territories and their inhabitants, some, but not all, of the provisions of the U.S. Constitution apply ex proprio vigore in our territorial possessions-is still good law. Most observers will not know the real context of the old cases, and the current Supreme Court neglects to acknowledge the continuing effect of those decisions on over four million citizens of the United States who have lived with the rule of the Insular Cases for the 109 years since it was first articulated in Downes v. Bidwell. ${ }^{4}$

This article seeks to start to remedy those shortcomings by presenting the Insular Cases in their historical and sociological context to illustrate how the Court's interpretation of the Territorial Clause constitutionally "inconveniences" the territorial citizens by relegating them to second-class legal status, and

\footnotetext{
2 Boumediene v. Bush, 553 U.S. 723 (2008).

3 Boumediene, 553 U.S. at 759.

4 Downes v. Bidwell, 182 U.S. 244 (1901).
} 


\section{arguing that the solution to the problem created by the Insular Cases lies in overruling Downes's use of the Territorial Clause to situationally pick and choose which constitutional provisions will be enforced in the territories. ${ }^{5}$}

5 I began this article a few weeks after the Boumediene decision was issued as an attempt to greatly expand a short contribution to an anthology into an article, see The Story of Downes, supra note 1, and to discuss the Supreme Court's most recent citation of the Insular Cases. First a law review placement blunder on my part, and then a family tragedy forced me to move on to other projects and delay its publication. I posted an early version of this article on the BePress service and sent it off for publication in the fall of 2008. Within two days, I had two offers to publish it, including one from a symposium issue dedicated to the case. Unfortunately, I declined them. Luckily, this delay has provided the opportunity to review the literature produced in response to the case, and to re-assess the article's original conclusion that the Insular Cases were not seriously studied in U.S. law generally and in constitutional law in particular. A LEXIS search of published law review articles found 506 articles that referenced Boumediene in their text. When that search was refined to articles referencing Boumediene and the Insular Cases together, it produced 48 article results. (Both searches were conducted in March 2010. The first simply found references to "Boumediene w/5 Bush" in the previous two years. The second searched for the case name and the phrase "Insular Cases" in the same text, during the same time period).

An analysis of those cites found that the references to the Insular Cases were generally in passim and few authors studied the history of those cases. See, e.g., Ernesto Hernández-López, Boumediene v. Bush and Guantánamo, Cuba: Does the "Empire Strike Back"?, 62 SMU L. REV. 117, 142-49 (2009) (providing an overview of the Insular Cases in an article studying the legal relationship between the U.S. and Cuba, and the claims over Guantánamo Naval Station). Two well-known federal judges of Puerto Rican descent have also written substantial articles on this subject. See José A. Cabranes, Our Imperial Criminal Procedure: Problems in the Extraterritorial Application of U.S. Constitutional Law, 118 YALE L.J. 1660 (2009); Juan Torruella, The Insular Cases: The Establishment of a Regime of Political Apartheid, 77 REV. JUR. U.P.R. 1 (2008). But there were some exceptions; significantly, the work of Christina Duffy Burnett, who, in a recent article entitled $A$ Convenient Constitution? Extraterritoriality After Boumediene, seeks to place Boumediene and the Insular Cases in the context of "Fourteenth Amendment incorporation" jurisprudence, rather than in what she calls the "Territory Clause" (Territorial Clause) of the U.S. Constitution (Article IV, section 3, clause 2). Christina Duffy Burnett, A Convenient Constitution? Extraterritoriality After Boumediene, 109 ColUM. L. REV. 973, 973 (2009) [hereinafter A Convenient Constitution]; By bringing the two lines of cases together, she hopes to provide a more sound way to resolve the constitutional questions that arise in these situations. $A$ Convenient Constitution, supra, at 1042 ("T have challenged the idea that there should be two separate and unrelated ways of handling questions of constitutional scope and content, one for the domestic setting and another abroad. I have illustrated the point with a review of the Fourteenth Amendment incorporation cases, which concern essentially the same questions that the jurisprudence on constitutional extraterritoriality confronts."). While I wish that the Supreme Court decided and cited the Insular Cases as decisions about the due process owed to full citizens of the United States, see infra 
Part I of this article will discuss the Supreme Court's recent use of the Insular Cases to support its decision on the constitutional question of suspension or availability of habeas corpus for the persons imprisoned in Guantánamo Bay. Parts IIIV will then put the Insular Cases and their primary decision, Downes v. Bidwell, in their proper social, historical, and legal contexts. Parts V and VI will continue with the legal context for the decision - the series of cases now labeled as the Insular Cases-and their evolution from decisions issued by a deeply divided Supreme Court into a well-accepted constitutional rule that endures today. Finally, this article will engage in a brief critical analysis of the enduring effects of Downes and conclude with what it tells us about the possible long-term implications of Boumediene and why we should engage in more serious studies of the Insular Cases.

\section{BOUMEDIENE V. BUSH: THE INSULAR CASES IN THE TWENTY- FIRST CENTURY}

Let us begin on what was supposed to be the last day of the Supreme Court term, when the justices issued an anxiously awaited decision on a case that has made front-page-news throughout their term. The case raised questions about the

Part VII, that is not what the Court has chosen to do so far, though hopefully it will consider Burnett's suggestions. Nevertheless, Burnett's work provides an unorthodox take on and a review of the orthodox constitutional law literature's analysis of the Insular Cases.

For other unorthodox takes on the Insular Cases, see AMERICA's COLONY, supra note 1; EDIBERTO ROMÁN, THE OTHER AMERICAN COLONIES: AN INTERNATIONAL AND

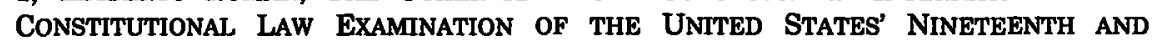
Twentieth Century Island Conquests (2006); Pedro A. Malavet, Puerto Rico: Cultural Nation, American Colony, 6 MICH. J. RACE \& L. 1, 21-40 (2000); Ediberto Román, The Alien-Citizen Paradox and Other Consequences of U.S. Colonialism, 26 FLA. ST. U. L. REV. 1 (1998). For unorthodox takes on American Law more generally, see RACE LAW STORIES, supra note 1; RICHARD DELGADO ET AL., LATINOS AND THE LAW: CASES AND MATERIALS (2008); JUAN F. PEREA ET AL., RACE AND RACES: CASES AND RESOURCES FOR A DIVERSE AMERICA (2000) [hereinafter RACE AND RACES]; DOROTHY A. BROWN, Critical Race Theory: Cases, Materials and Problems (2d ed. 2007); EMMa COLEMAN JORDAN \& ANGELA P. HARRIS, ECONOMIC JUSTICE: RACE, GENDER, IDENTITY and Economics, CASES AND Materials (2005); Critical RACE TheORY: THE KEY WRITINGS THAT FORMED THE MOVEMENT (Kimberlé Crenshaw et al. eds., 1995). 
power of the United States government to deal with the aftermath of a fast and tactically successful war as a result of which our armed forces are in effective control of a previously foreign territory, but facing various degrees of resistance ranging from political wrangling to violent and bloody insurgency. The year, however, is not 2008; it is 1901 .

The May 27, 1901 ruling of the United States Supreme Court in Downes v. Bidwell, ${ }^{6}$ particularly Justice Edward Douglass White's plurality opinion, ${ }^{7}$ is today the most important of the Insular Cases. With the U.S. Armed Forces facing a guerilla war in the Philippines ${ }^{8}$ and political wrangling in Cuba and Puerto Rico following the Spanish-American War, the policy motivations for the result in this case were straightforward. The United States was becoming a world power-a superpower in today's parlance. This power was principally expressed by deploying a large navy, which in turn required overseas bases of operations, and at the turn of the twentieth century that meant an imperial nation capable of holding colonies on which to establish military bases all over the world. ${ }^{9}$ Downes effec-

6 Downes v. Bidwell, 182 U.S. 244 (1901).

7 Id. at 287-344.

8 Whether to call the conflict in the Philippines a war, an insurrection, an insurgency, or something else, is a matter of some controversy. See generally DAVID J. SILBEY, A WAR OF FroNTIER AND EMPIRE: THE PHILIPPINE-AMERICAN WAR, 1899-1902 (2007) (describing the Philippine insurgency that followed the United States victory in the Spanish-American War; the Introduction addresses the debate over what to label the conflict). President McKinley put it this way in his second inaugural address on March 4, 1901: "We are not waging war against the inhabitants of the Philippine Islands. A portion of them are making war against the United States." Second Inaugural Address of William McKinley: Monday, March 4, 1901, THE AVALON ProJect: DOCUMENTS IN LAW, HISTORY AND DIPLOMACY, http://avalon.law.yale.edu/19th_centu ry/mckin2.asp (last visited Mar. 15, 2010).

9 See generally WARREN ZIMMERMANN, FIRST GREAT TRIUMPH: How FIVE AMERICANS MADE THeir CounTRY A WORLD POWER 8 (Farrar, Straus \& Giroux 2002) ("John Hay, Captain Alfred T. Mahan, Elihu Root, Henry Cabot Lodge, and Theodore Roosevelt can fairly be called the fathers of modern American imperialism and the men who set the United States on the road to becoming a great power."). See also BARTHOLOMEW H. SPARROW, THE INSULAR CASES AND THE EMERGENCE OF AMERICAN EMPIRE (2006), which describes "how the United States handled its first major episode of globalization and how the Supreme Court, in [the Insular Cases], crucially redirected the course of American history." Publisher Comments on THE INSULAR CASES AND THE EMERGENCE OF AMERICAN EMPIRE, http://www.kansaspress.ku.edu/spains.html (last visited Mar. 15, 2010). 
tively provides constitutional authorization for this process, by reinterpreting the Territorial Clause of the Constitution to abandon the old rule that the Constitution follows the flag to our territories in toto, and instead giving to Congress almost unfettered authority to deal with the territorial possessions by picking and choosing the constitutional provisions that will be allowed to apply in the territorial possessions.

Some may consider a 1901 case to be ancient history, but Downes and its progeny are still applicable law, as shown most recently by Boumediene. Yet, while partially basing its ruling on Downes, the Boumediene Court neglected to acknowledge that Downes and its progeny are most pertinent to the current territorial possessions of the United States, and their population of more than four million-for the most part-citizens of the United States.

Fast-forward to 2008. Associate Justice Anthony M. Kennedy, writing for the majority of the United States Supreme Court in Boumediene - joined by Associate Justices John Paul Stevens, David Hackett Souter, Ruth Bader Ginsburg, and Stephen G. Breyer ${ }^{10}$-rearticulated the relevance of the Insular Cases as follows:

Fundamental questions regarding the Constitution's geographic scope first arose at the dawn of the 20th century when the Nation acquired noncontiguous Territories: Puerto Rico, Guam, and the Philippines-ceded to the United States by Spain at the conclusion of the Spanish-American Warand Hawaii-annexed by the United States in 1898. At this point Congress chose to discontinue its previous practice of extending constitutional rights to the territories by statute.

In a series of opinions later known as the Insular Cases, the Court addressed whether the Constitution, by its own force, applies in any territory that is not a State. The Court held that the Constitution has independent force in these ter-

10 The Justices' names and order of seniority are as listed in their official biographies published by the Court. See The Justices of the Supreme Court, SUPREME CoURT OF THE UNITED STATES, http://www.supremecourt.gov/about/biographiescurrent.pdf (last visited Mar. 15, 2010) (the current posting includes the biography of the nowretired Justices O'Connor and Souter). 
ritories, a force not contingent upon acts of legislative grace.

Yet it took note of the difficulties inherent in that position. ${ }^{11}$

While many will hail the majority decision because its result guarantees constitutional rights to human beings being held by U.S. authorities well outside of a combat-zone, at least for the time being, this introduction by the Court in fact sets up the discussion of yet another rationalization of why "other"12 people should not be "burdened" with the full range of rights guaranteed by our Constitution unless the Supreme Court finds it convenient for the United States. Rather than having "the Constitution follow the flag," i.e., ruling that all provisions of the Constitution, especially those that guarantee individual rights, apply ex proprio vigore to territorial subjects, the $\mathrm{Su}$ preme Court articulated a flexible test that gives great deference to the political branches of government. The Court chose to engage in a case-by-case and right-by-right analysis to decide which of the individual protections guaranteed in the Constitution to U.S. citizens in the territory of a U.S. state should be conferred upon U.S. citizens and non-citizens found in U.S. custody in a territory controlled by the U.S. that has not been incorporated into the union as a state. The rationalization of avoiding "overburdening" the different "cultures" acquired as spoils of the Spanish-American War today gives way to the needs of the so-called war on terror. As I discuss further below, on both occasions, the principal beneficiary of this flexibility is the federal government-both at the executive and legislative levels-because they are given almost unfettered authority to deal with large groups of persons who, often in spite of their U.S. citizenship, are to be treated as lesser citizens and ulti-

\footnotetext{
11 Boumediene v. Bush, 553 U.S. 723, 756-57 (2008).

12 In general, as used herein, "other" and "othering," i.e., to be "othered," means to be socially constructed as "not normative." See, e.g., Cathy J. Cohen, Straight Gay Politics: The Limits of an Ethnic Model of Inclusion, in ETHNICITY AND GROUP RIGHTS 572, 580 (Ian Shapiro \& Will Kymlicka eds., 1997) ("Much of the material exclusion experienced by marginal groups is based on, or justified by, ideological processes that define these groups as 'other.' Thus, marginalization occurs, in part, when some observable characteristic or distinguishing behavior shared by a group of individuals is systematically used within the larger society to signal the inferior and subordinate status of the group.") (citation omitted).
} 
mately as lesser human beings. In the words of the majority in Boumediene.

As the Court later made clear, "the real issue in the Insular Cases was not whether the Constitution extended to the Philippines or Porto Rico when we went there, but which of its provisions were applicable by way of limitation upon the exercise of executive and legislative power in dealing with new conditions and requirements." 13

While the Supreme Court then and now characterizes this constitutional "flexibility" as both desirable and necessary, the end result of these opinions has been to leave too much discretion to the political branches of government at a time when judicial review was most needed to guarantee the basic human rights of new subjects of United States law. The territorial subjects of the United States by definition live in areas that lack full representation in the United States House of Representatives and Senate, and they are not allowed to vote in presidential elections. That leaves them without meaningful participation in the process of law making and enforcement by the United States, even though the United States is the ultimate legal authority over them and their territory. ${ }^{14}$

In order to justify this policy, the majority opinion in Boumediene focused on the Philippines and the "assumption" that they would become independent. That did indeed happen, forty-five years after the 1900 Supreme Court term ended.15 Cuba, another territory acquired as a result of the SpanishAmerican War, was granted independence by the treaty that ended that war, but subject to U.S. rule, which severely limited its sovereignty for decades. ${ }^{16}$ The majority opinion did not in

13 Boumediene, 553 U.S. at 758.

14 See generally AMERICA's COLONY, supra note 1, at 47, 134, 155 (discussing “democracy deficit" in the relationship between the territory of Puerto Rico and the United States).

16 The official date when Philippine Independence was recognized by the United States is July 4, 1946. See Proclamation No. 2695, 3 C.F.R. 64 (1946 Supp.), reprinted as amended in 22 U.S.C. $\$ 1394$ (2006), and in 60 Stat. 1352 (1946).

16 See Treaty of Paris, 1898, in 1 P.R. LAWS ANN., at 16 (2008) (ending Spanish sovereignty over Cuba, subject to U.S. occupation). The Platt Amendment of 1901 official- 
any way expressly acknowledge the fate of Guam and Puerto Rico, which were then and are still territories of the United States subject to the rule of the Insular Cases. For the territorial citizens this is not a temporary transition on the way to independence, rather it is a permanent status of constitutional inferiority imposed by the U.S. Supreme Court and enforced by the executive and legislative branches now for over one hundred years.

The majority opinion characterized the policy behind the Insular Cases thusly: "The Court thus was reluctant to risk the uncertainty and instability that could result from a rule that displaced altogether the existing legal systems in these newly acquired territories." 17

No such qualms were on display during the westward expansion of the United States. The Constitution did in fact "displace[ altogether the existing legal systems [of the] newly acquired Territories," of the American West, with the full legal support of the Supreme Court. ${ }^{18}$ The local law in Puerto Rico or

ly recognized Cuban sovereignty, subject to severe conditions imposed by the United States. The United States Department of State describes the Amendment as follows:

While the amendment was named after Senator Orville Platt of Connecticut, it was drafted largely by Secretary of War Elihu Root. The Platt Amendment laid down eight conditions to which the Cuban Government had to agree before the withdrawal of U.S. forces and the transfer of sovereignty would begin. ... Although the Cuban [Constitutional Convention] delegates realized that the amendment significantly limited Cuban sovereignty, and originally refused to include it within their constitution, the U.S. Government promised them a trade treaty that would guarantee Cuban sugar exports access to the U.S. market. After several failed attempts by the Cubans to reject or modify the terms of the Platt amendment, the Cuban Constitutional Convention finally succumbed to American pressure and ratified it on June 12,1901, by a vote of 16 to 11. The Platt Amendment remained in force until 1934 when both sides agreed to cancel the treaties that enforced it.

See Milestones: 1899-1913, The United States, Cuba, and the Platt Amendment, 1901, U.S. DEP'T OF STATE, OFFICE OF THE HISTORIAN, http://history.state.gov/milestones/18 99-1913/Platt (last visited Mar. 15, 2010). The official end of this regime with the Treaty of 1934 is discussed infra notes $28-29$ and accompanying text.

17 Boumediene, 553 U.S. at 757. ("It is obvious that in the annexation of outlying and distant possessions grave questions will arise from differences of race, habits, laws and customs of the people, and from differences of soil, climate and production ..." (quoting Downes v. Bidwell, 182 U.S. 244, 282 (1901))).

18 See discussion infra notes $171-72$ and accompanying text. 
Guam was not any more threatened by the application of constitutional provisions than was the law of Louisiana, California, Texas, Florida, or New York. The only legal system being protected here is that of the United States to maintain a colonial empire. Nevertheless, as the majority continues to explain the "situational" standard for the application of constitutional limitations on the powers of Congress: "These considerations resulted in the doctrine of territorial incorporation, under which the Constitution applies in full in incorporated Territories surely destined for statehood but only in part in unincorporated Territories." 19

The majority went on to explain that some basic "personal rights" guaranteed by the U.S. Constitution must be applied ex proprio vigore to non-citizens (and, as explained below, to U.S. citizens as well) in the territorial possessions: "[A]s early as Balzac in 1922, the Court took for granted that even in unincorporated Territories the Government of the United States was bound to provide to noncitizen inhabitants 'guaranties of certain fundamental personal rights declared in the Constitution." 20

The majority emphasized that it will identify which rights will be guaranteed in any particular territory at any particular time, but it will exercise that discretion so as to give Congress (and implicitly the executive branch as well) substantial lee-

19 Boumediene, 553 U.S. at 726. The statement is supported by a quote from Dorr v. United States.

Until Congress shall see fit to incorporate territory ceded by treaty into the United States, ... the territory is to be governed under the power existing in Congress to make laws for such territories and subject to such constitutional restrictions upon the powers of that body as are applicable to the situation.

195 U.S. 138, 143 (1904) (emphasis added). The Court also quotes Justice White's concurring opinion in Downes. "[T] Constitution is applicable, generally speaking, in all cases, involves an inquiry into the situation of the territory and its relations to the United States." Downes, 182 U.S. at 293. The incorporation doctrine is discussed infra Part VI.

20 Boumediene, 553 U.S. at 758. The statement is supported by citing Late Corp. of Church of Jesus Christ of Latter-day Saints v. United States. "Doubtless Congress, in legislating for the Territories would be subject to those fundamental limitations in favor of personal rights which are formulated in the Constitution and its amendments." 136 U.S. 1, 44 (1890). 
way: "Yet noting the inherent practical difficulties of enforcing all constitutional provisions 'always and everywhere,' the Court devised in the Insular Cases a doctrine that allowed it to use its power sparingly and where it would be most needed. This century-old doctrine informs our analysis in the present matter."21

The majority then proceeded to "hold that Art. I, § 9, cl. 2, of the Constitution has full effect at Guantanamo Bay. If the privilege of habeas corpus is to be denied to the detainees now before us, Congress must act in accordance with the requirements of the Suspension Clause."22

Associate Justices Souter, Ginsburg, and Breyer concurred in a brief opinion authored by Souter. They did not mention the Insular Cases at all but rather focused on responding to the dissenting justices' arguments regarding habeas corpus statutes. The concurrence also responded to the part of Justice Scalia's dissenting opinion rejecting the majority's acceptance of de facto as distinguished from de jure sovereignty. ${ }^{23}$

The four remaining justices-Chief Justice John G. Roberts, Jr., and Associate Justices Antonin Scalia, Clarence Thomas, and Samuel Anthony Alito, Jr. ${ }^{24}$-dissented, expressing their views in two written opinions joined by all four. The first dissent, authored by the Chief Justice, did not mention the Insular Cases at all. ${ }^{25}$ Justice Scalia's dissent stated that there is only one kind of sovereignty: de jure. In his opinion, sovereign control is the key to the application of habeas corpus, and neither the Suspension Clause nor the Insular Cases are at all applicable in this situation because we lack sovereignty over Guantánamo. He wrote:

Eisentrager thus held-held beyond any doubt-that the Constitution does not ensure habeas for aliens held by the United States in areas over which our Government is not sovereign.

\footnotetext{
21 Boumediene, 553 U.S. at 758-59.

22 Id. at 771.

23 Id. at 799.

24 See supra note 10.

25 Boumediene, 553 U.S. at 801-26.
} 
The Court also reasons that Eisentrager must be read as a "functional" opinion because of our prior decisions in the Insular Cases. It cites our statement in Balzac v. Porto Rico that "the real issue in the Insular Cases was not whether the Constitution extended to the Philippines or Porto Rico when we went there, but which of its provisions were applicable by way of limitation upon the exercise of executive and legislative power in dealing with new conditions and requirements." But the Court conveniently omits Balzac's predicate to that statement: "The Constitution of the United States is in force in Porto Rico as it is wherever and whenever the sovereign power of that government is exerted." The Insular Cases all concerned territories acquired by Congress under its Article IV authority and indisputably part of the sovereign territory of the United States. None of the Insular Cases stands for the proposition that aliens located outside U.S. sovereign territory have constitutional rights, and Eisentrager held just the opposite with respect to habeas corpus. As I have said, Eisentrager distinguished Yamashita on the ground of "our sovereignty [over the Philippines]."26

The majority simply read Eisentrager differently.

The Court's holding in Eisentrager was thus consistent with the Insular Cases, where it had held there was no need to extend full constitutional protections to territories the United States did not intend to govern indefinitely. Guantánamo Bay, on the other hand, is no transient possession. In every practical sense Guantánamo is not abroad; it is within the constant jurisdiction of the United States. ${ }^{27}$

Having articulated how it applied to the Guantánamo situation, the majority argued that although the rule of the Insular Cases is a firm constitutional doctrine, it is not intended for indefinite application in any one territory. This statement, however, is belied by the experience of the current territorial possessions, as developed later in this article. Nevertheless, to illustrate its contention that the rule of the Insular Cases is

26 Id. at 855-89 (Scalia, J., dissenting) (citations and footnote omitted).

27 Id. at 553 U.S. at 768-69 (majority opinion) (citation omitted) (emphasis added). 
intended to apply in temporary and transitional situations, the majority of the Court placed its focus and emphasis on Cuba and the Philippines as territories that were held only temporarily and transitionally-except of course for Guantánamo. The majority almost completely ignored the current status of Guam and Puerto Rico as territorial possessions that have been subjected to the rule of the Insular Cases for an indefinite period of time. Guantánamo Bay itself remains under U.S. rule, even though all members of the Court stated that the Republic of Cuba has sovereignty over that land. ${ }^{28}$ The U.S. government

28 U.S. control over Guantánamo Bay Naval Station was legally established by a treaty and then a "lease." See Agreement between Cuba and the United States for the Lease of Lands for Coaling and Naval Stations, in 192 THE CoNSOLIDATED TREATIES SERIES 429-30 (Clive Parry ed., 1980); Convention between Cuba and the United States for the Establishment of Naval and Coaling Stations at Guantánamo and Bahia Hon$d a$, in 193 The Consolidated TREaties Series 314-16 (Clive Parry ed., 1980). Under the Treaty of February 23, 1903, de jure sovereignty over Guantánamo Naval Station belongs to the Cuban government, but de facto control belongs to the United States. Article III of the Treaty of February 23, 1903, reads:

While on the one hand the United States recognizes the continuance of the ultimate sovereignty of the Republic of Cuba over the above described areas of land and water, on the other hand the Republic of Cuba consents that during the period of the occupation by the United States of said areas under the terms of this agreement the United States shall exercise complete jurisdiction and control over and within said areas with the right to acquire (under conditions to be hereafter agreed upon by the two Governments) for the public purposes of the United States any land or other property therein by purchase or by exercise of eminent domain with full compensation to the owners thereof.

192 The Consolidated TReaties Series, at 430 (emphasis added). The majority in Boumediene accepted the government's position regarding sovereignty over Guantánamo. The Court explained:

[F]or purposes of our analysis, we accept the Government's position that $\mathrm{Cu}$ ba, and not the United States, retains de jure sovereignty over Guantánamo Bay. As we did in Rasul, however, we take notice of the obvious and uncontested fact that the United States, by virtue of its complete jurisdiction and control over the base, maintains de facto sovereignty over this territory.

Boumediene, 553 U.S. at 775. As noted above, the dissenters felt that the matter of de jure sovereignty was decisive on this case. However, the majority ruled that the constitutional habeas corpus Suspension Clause is binding upon the United States in territory under its de facto sovereignty. Id.; see also Rasul v. Bush, 542 U.S. 466, 484 (2004) (6-3 ruling that statutory habeas corpus was available to persons held by the United States in territory under the de jure sovereignty of another country, but de facto con- 
"lease" of Guantánamo is, from the American perspective, indefinite, in that the U.S. takes the position that both sides must agree to terminate the lease or to change its provisions in any way. ${ }^{29}$ Accordingly, the suggestion that the constitutionallyflexible case-by-case approach adopted by the majority is not going to be applied indefinitely in a particular territory is a rank fallacy.

Moreover, the majority's only acknowledgement of one of the current territorial possessions subject to U.S. sovereignty, Puerto Rico, makes it clear that the almost four million U.S. citizens living there have only the constitutional rights that the Court "situationally"-and from my perspective most inconveniently-chooses to allocate to them. Specifically, the majority opinion stated that it is possible for the bundle of rights applicable in a particular territory to change over time. It wrote:

It may well be that over time the ties between the United States and any of its unincorporated Territories strengthen in ways that are of constitutional significance. [Compare] Torres v. Puerto Rico: "Whatever the validity of the [Insular Cases] in the particular historical context in which they were de-

trol of the United States; Justice Scalia, Chief Justice Rehnquist, and Justice Thomas dissented).

29 This is based on the language of the original Treaty of February 23, 1903, as modified by the 1934 Treaty that legally ended the regime that expressly allowed direct interference by the United States in internal Cuban affairs. See Treaty of 1934, 48 Stat. 1682 (1934). Article III of the Treaty reads in pertinent part:

So long as the United States of America shall not abandon the said naval station of Guantánamo or the two Governments shall not agree to a modification of its present limits, the station shall continue to have the territorial area that it now has, with the limits that it has on the date of the signature of the present Treaty.

Id. at 1683. Prior to 1934, legal authorization for unilateral U.S intervention in Cuba was guaranteed by an additional agreement signed in 1903. See Treaty between Cuba and the United States determining their Relations, in 193 THE CONSOLIDATED TREATIES SERIES, supra note 28, at 198-201 (Article III provides: "That the government of Cuba consents that the United States may exercise the right to intervene for the preservation of Cuban independence, the maintenance of a government adequate for the protection of life, property, and individual liberty, and for discharging the obligations with respect to Cuba imposed by the Treaty of Paris on the United States, now to be assumed and undertaken by the government of Cuba."). The Treaty of May 22, 1903, was generally superseded by the Treaty of 1934 . 
cided, those cases are clearly not authority for questioning the application of the Fourth Amendment-or any other provision of the Bill of Rights-to the Commonwealth of Puerto Rico in the 1970's." 30

The "constitutionally significant" change that the majority anticipates is one that might expand (or contract) the "personal rights" guaranteed by the Constitution to the territorial subjects or citizens. The fundamental constitutional nature of the relationship between the United States and its territories will not change, however, because that will still be governed by the Territorial Clause as interpreted by the Insular Cases. The right to choose which constitutional provision(s) will apply in the territories is the crux of the Court's use of the Territorial Clause to create the so-called "doctrine of the Insular Cases" and their progeny.

The only thing that remains clear after Boumediene is the so-far indefinite and continuous application of the Insular Cases to the territorial citizens, subjects and possessions of the United States acquired following the Spanish-American War. Though they disagree as to whether those cases apply to the Guantánamo detentions, all members of the current Supreme Court clearly agree that the Insular Cases are still good law. The entire Court is also unanimous that the White plurality in Downes, as adopted in Balzac, is the primary articulation of the rule of the Insular Cases. The remainder of this article explains and critiques how a three-judge plurality issued by a deeply divided Court in 1901 became the firmly established rule, as expressly recognized by Balzac in 1922, and remains in vigor to this day.

30 Boumediene, 553 U.S. at 758 (quoting Torres v. Puerto Rico, 442 U.S. 465, 47576 (1979) (Brennan, J., concurring in judgement)). 


\section{SOCIAL, HISTORICAL, AND LEGAL CONTEXT: OUR ISLANDS AND THEIR PEOPLE ${ }^{31}$}

Our Constitution does not refer to insular possessions; rather, it uses the label "territory," in the aptly labeled Territorial Clause of the Constitution of the United States, which reads: "The Congress shall have Power to dispose of and make all needful Rules and Regulations respecting the Territory or other Property belonging to the United States; and nothing in this Constitution shall be so construed as to Prejudice any Claims of the United States, or of any particular State."32

Initially, the Clause was applied to most of the thirtyseven territories that became states after the original thirteen colonies. ${ }^{33}$ For example, Alaska and Hawaii are current states that were regulated by legislation passed by Congress pursuant to the Territorial Clause, but that legislation was repealed or became obsolete after statehood. ${ }^{34}$ Right now, and legally as a result of the Insular Cases, as Arnold Leibowitz explains:

31 See generally Jose De OLIVARES, OUR ISLANDS AND THEIR PEOPLE AS SEEN WITH CAmera AND Pencil (William S. Bryan ed., N.D. Thompson Publishing Co. 1899). This is a large two-volume coffee-table book set purportedly describing the new island territories that were sold door-to-door after the war.

32 U.S. CONST. art. IV, § 3, cl. 2.

33 The possible exception is Texas, which, from the American perspective, seceded from Mexico and became a state of the union after being an "independent Republic." But that left open the period between the congressional annexation vote on March 1, 1845, and the formal statehood admission in December of 1845. In De Lima v. Bidwell, the majority notes: "Texas remained a foreign state until December 29, [1845], when she was formally admitted." 182 U.S. 1, 191 (1901). For a succinct distinction between the continental territories and the island territories, see ARNOLD H. LEIBOWITZ, Defining STATUS: A Comprehensive ANAlysis of UNITED STATes TeRritorial RELATIONS 4-16 (Kluwer Academic 1989).

34 As to Alaska, see 48 U.S.C. $§ 21$ (2006); as to Hawaii, see 48 U.S.C. $\$ 491$ (2006). Alaska was officially admitted into statehood on January 3, 1959. See Proclamation No. 3269, 73 Stat. c16 (1959); Act of 1958, Pub. L. No. 85-508, 72 Stat. 339 (1958). Hawaii was admitted by law as of March 18, 1959. See Act of 1959, Pub. L. No. 86-3, 73 Stat. 4 (1959). But section 2 of this law excepted "the atoll known as Palmyra Island, together with its appurtenant reefs and territorial waters, but said State shall not be deemed to include the Midway Islands, Johnston Island, Sand Island (offshore from Johnston Island), or Kingman Reef, together with their appurtenant reefs and territorial waters." 73 Stat. at 4. 
The United States [is] . . . the largest overseas territorial power in the world. [It] now governs five areas (Puerto Rico, [the] Virgin Islands, Guam, the Northern Marianas, and American Samoa) with a population of almost four million people[,] and has special responsibilities for three additional areas (Federated States of Micronesia, the Marshall Islands and Palau). ${ }^{35}$

In the era pertinent to the Insular Cases, statutes passed on the authority of the Territorial Clause refer to these as "possessions," "insular possessions," or "insular areas."36 Pursuant to these statutes, the United States controls or has a legal relationship with the eight populated island territories named above, and controls several unpopulated islands. ${ }^{37}$ The populated territories collectively have well over four million resi-

\footnotetext{
35 LEIBOWITZ, supra note 33, at 3.

36 See generally 48 U.S.C. (2006). The Department of the Interior's Office of Insular Affairs currently defines the term as follows:

A jurisdiction that is neither a part of one of the several States nor a Federal district. This is the current generic term to refer to any commonwealth, freely associated state, possession or territory or Territory [sic] and from July 18, 1947, until October 1, 1994, the Trust Territory of the Pacific Islands. Unmodified, it may refer not only to a jurisdiction which is under United States sovereignty but also to one which is not, i.e., a freely associated state or, 194794, the Trust Territory of the Pacific Islands or one of the districts of the Trust Territory of the Pacific Islands.
}

Definitions of Insular Area Political Organizations, U.S. DEP'T OF THE INTERIOR, OFFICE OF INSULAR AFFAIRS, http://www.doi.gov/oia/Islandpages/political_types.htm (last visited Mar. 15, 2010).

37 In its "Island Fact Sheet," the Department of the Interior's Office of Insular Affairs identifies unpopulated island territories of the United States under designated categories: U.S. Territories under OIA are Palmyra Atoll (Excluded Areas) and Wake Atoll (Residual Administration); U.S. Territories under U.S. Fish and Wildlife Jurisdiction, often referred to as the Guano Islands, are Baker Island, Howland Island, Jarvis Island, Johnston Atoll . . Kingman Reef, Navassa Island and Palmyra Atoll. All OLA Jurisdictions, U.S. DEP'T OF THE INTERIOR, OFFICE OF INSULAR AFFAIRS, http://www. doi.gov/oia/Firstpginfo/islandfactsheet.htm (last visited Mar. 15, 2010). See generally LEIBOWITZ, supra note 33, at 3. On the Guano Islands, see 48 U.S.C. $\$ 1411$ (2006) ("Whenever any citizen of the United States discovers a deposit of guano on any island, rock, or key, not within the lawful jurisdiction of any other government, and not occupied by the citizens of any other government, and takes peaceable possession thereof, and occupies the same, such island, rock, or key may, at the discretion of the President, be considered as appertaining to the United States."). 
dents, ${ }^{38}$ and among this group, only the Samoans are not citizens of the United States. ${ }^{39}$

Several unpopulated islands, and the eight populated island territories of the United States and any U.S. national or citizen living in or traveling to them is currently subject to the constitutional doctrine of the Insular Cases issued in the days of President William McKinley. ${ }^{40}$

\section{PUERTO RICO IN 1901: SELF-GOVERNMENT AND SPANISH CITIZENSHIP THAT DID NOT LAST LONG}

For Puerto Rican islanders, the Insular Cases were not simply the start of their second colonial period, but the extension of 400 years of colonial status that initially deprived them of legal citizenship in the country that ruled over them.

Puerto Rico is a group of islands bordered by the Atlantic Ocean and Caribbean Sea. The main island is known as Puerto Rico and is joined by adjacent smaller islands that include Vieques, Culebra, Mona, and Monito. ${ }^{41}$ The main island-which is

38 The Puerto Rican population of 3.9 million, discussed infra note 43 and accompanying text, far exceeds the populations of other island territories, which the 2000 Census found were as follows: American Samoa, 57,291; Guam, 154,805; the U.S. Virgin Islands, 108,612; and The Commonwealth of the Northern Mariana Islands (CNMI), 69,221. United States Census 2000: The Island Areas, U.S. CENSUS BUREAU, http://www.census.gov/population/www/cen2000/islandareas.html (last visited Mar. 15, 2010).

39 See LEIBOWTT, supra note 33, at 449-51 (though expressing some doubt about the matter, noting that American Samoans are treated as "non-citizen nationals" of the United States). The three so-called Free Associated States-The Republic of the Marshall Islands, the Federated States of Micronesia, and Palau-are members of the United Nations. See Member States of the United Nations, UNITED NATIONS WEBSITE, http://www.un.org/en/members/index.shtml (last visited Mar. 15, 2010). The Marshall Islands and the Federated States of Micronesia were admitted on September 17, 1991, and Palau was admitted on December 15, 1994. They have their own citizenship, independent from the United States. See generally LEIBOWITZ, supra note 33, at 639-703. As of July 2010 , their populations are estimated, respectively, at $65,859,107,154$, and 20,879. See The World Factbook, CENTRAL INTELLIGENCE AGENCY, https://www.cia.gov/ library/publications/the-world-factbook/index.html (last visited Mar. 15, 2010).

40 See, e.g., Torres v. Puerto Rico, 442 U.S. 465 (1979), discussed infra section VI. See also MARGARET LEECH, IN THE DAYS OF MCKINLEY (1959).

41 See 48 U.S.C. \$ 731 (2006) ("The provisions of this [Act] shall apply to the island of Puerto Rico and to the adjacent islands belonging to the United States and waters of 
roughly 160 kilometers long and 53 kilometers wide and contains most of Puerto Rico's 8959 square kilometers of land area-is the home of all but a few thousand of its inhabitants. Therefore, the archipelago is generally referred to as the Isla del Encanto (enchanted island or isle of enchantment) or, simply, the "island." For about five centuries before Christopher Columbus claimed the territory for Spain in 1493, Taino and Carib natives lived on the Puerto Rican islands. But the Spanish colonial period lasted for a little more than four centuries, during which the Spaniards created the racial, legal, political, and cultural composition of the Puerto Ricans. ${ }^{42}$

Puerto Rico is the most populous of the current island territories with current estimates placing the number of residents at $3,927,188$, and was involved in most of the Insular Cases. ${ }^{43}$ Other U.S. citizens have not moved to Puerto Rico in substantial numbers, however, ${ }^{44}$ and Puerto Rico remains a culturally Latina/o island even after more than one hundred years of U.S. occupation. Puerto Ricans are one of the largest Latina/o groups in the United States. The 2000 Census also found $3,406,178$ persons in the fifty states and the District of Columbia who identified themselves as "Hispanic or Latino" and specified "Puerto Rican" in their forms. ${ }^{45}$ On July 13, 2009, the

those islands; and the name Puerto Rico, as used in this [Act], shall be held to include not only the island of that name, but all the adjacent islands as aforesaid.").

42 See generally AMERICA'S CoLONY, supra note 1, at 49-116.

43 According to the 2000 Census, Puerto Rico's population was 3,808,610. United States Census 2000: Census 2000 Data for Puerto Rico, U.S. Census BurEaU, http://www.census.gov/census2000/states/pr.html (last visited Mar. 15, 2010). The estimate issued in 2010 is that the population has risen to 3,977,663. The World Factbook, Central America and Caribbean: Puerto Rico, CeNTral InTeldigence AgENCY, https://www.cia.gov/library/publications/the-world-factbook/geos/rq.html (last visited Mar. 15, 2010).

44 According to the 2000 U.S. Census-which provides the most detailed information-more than 3.8 million persons live in Puerto Rico, of whom 98.8 percent describe themselves as "Hispanic or Latino" and 95.1 percent as "Puerto Rican." DP-1. Profile of General Demographic Characteristics: 2000, Census 2000 Summary File 1, U.S. CENSUS BUREAU, AMERICAN FACTFINDER, http:/factfinder.census.gov/servlet/QTTable? bm=y\&-geo_id=04000US72\&-qr_name=DEC_2000_SF1_U_DP1\&-ds_name=DEC_20 00_SF1_U (last visited Mar. 15, 2010).

45 QT-P9. Hispanic or Latino by Type: 2000, Census 2000 Summary File 1, U.S. CENSUS BUREAU, AMERICAN FACTFINDER, http://factfinder.census.gov/servlet/QTTable? 
Pew Research Center reported that " 4.1 million Puerto Ricans resided in the fifty U.S. states and the District of Columbia in 2007, according to the Census Bureau's American Community Survey." 46 For the first time, the Puerto Rican population in the states exceeds that of the island.

On the eve of the Spanish-American War in 1898, Puerto Rico and Cuba were the last outposts of Spain in the Americas. ${ }^{47}$ The return of the Spanish Monarchy in 1814 meant the loss of Spanish citizenship and participation in the political process briefly granted by the 1812 Constitución de Cádiz (Constitution of Cadiz). White cubanas/os (Cubans) and puertorriqueñas/os were back to being subjects of Spain, but they were not its citizens. ${ }^{48}$ In a process that had started with the revolution of September 1868 in Spain and continued with the new constitution of $1876,{ }^{49}$ the Spanish crown began to reconsider the legal regime governing the islands of Cuba and Puerto Rico. Article 89 of the Constitution of the Spanish Monarchy of $\mathbf{1 8 7 6}$ gave the government the power to issue special legislation for the governance of the "provincias del ultramar" (the overseas provinces). Clause 2 of this article gave Cuba and Puerto Rico the right to be represented in the Cortes-the Spanish legislative body-once special legislation to that effect was approved. In a series of enactments, Cuba and Puerto Rico received increasing levels of home rule and the rights of Spanish citizens, but due to the turmoil in Spain, the constitutional

_bm=y\&-qr_name=DEC_2000_SF1_U_QTP9\&-geo_id=01000US\&-ds_name=DEC_2000 _SF1_U\&-redoLog=false (last visited Mar. 15, 2010).

46 A profile of Puerto Ricans, PEW RESEARCH CENTER, http://pewresearch.org/pubs/ 1280/profile-puerto-ricans-living-in-us (last visited Mar. 15, 2010).

47 The Spanish empire in the Americas was almost totally lost between 1821 and 1824, principally as a result of the Napoleonic invasion of the Tberian Peninsula. See JOSÉ TERRERO, HISTORIA DE ESPAÑa 456-58 (Juan Regla ed., Ramón Sopena 1971).

48 See generally AMERICA's CoLONY, supra note 1, at 32-33 (generally describing the effect of the Napoleonic occupation on Spanish law and in particular that persons of African ancestry had to apply for citizenship and meet further requirements under the royal constitution).

49 During the reign of Alfonso XII. See Constituciones y Códigos Polfiticos ESPAÑOLES, 1808-1978, at 145 (Julio Montero ed., Ariel 1998). 
authorization was not implemented in earnest until $1895 .{ }^{50}$ The reforms were more acceptable to the Puerto Ricans than to the Cubans. In the late 1890s, Luis Muñoz-Rivera, the leader of Puerto Rico's principal political group, the Autonomist Party, rejected plans for a military attack against the Spanish proposed by Puerto Rican pro-independence forces in exile in New York. ${ }^{51}$

As part of the autonomy process, Spanish citizenship was formally granted to the native-born inhabitants of Cuba and Puerto Rico in November 1897.52 On November 25, 1897, Spain legislated the Charter of Autonomy for Puerto Rico. The Charter granted self-government by an elected lower chamber of the legislature, a partially elected and partially appointed upper legislative chamber, and an appointed high executive known as the governor-general..$^{53} \mathrm{~A}$ separate decree extended the civil rights guarantees of the 1876 Spanish constitution to apply to Puerto Rico. ${ }^{54}$ The Charter of Autonomy set the stage for the final Spanish election in Puerto Rico. ${ }^{55}$ Puerto Rico's Autonomist and Liberal Parties welcomed the Charter and elected the country's first homegrown government just weeks before the start of the Spanish-American War. ${ }^{56}$ On July 17, 1898, the new local government was installed in San Juan. ${ }^{57}$

\footnotetext{
50 See generally ALFONSO L. GARCfA-MARTÍNEZ, PUERTO RICO: LEYES FundAMENTALES 9-114 (Editorial Edil 1989).

51 Olga JIMÉNEZ de WAgENHEIM, PUERTO Rico: AN INTERPRETIVE HiSTORY FROM PRE-Columbian TIMES To 1900, at 198-99 (1998). But in Cuba, General Máximo Gómez was still fighting the Spanish when the United States invaded Cuba in 1898.

62 Article 1 of the Decree of 9 November 1897 gives Spanish citizenship, on an equal footing with residents of the Peninsula, to the Spanish subjects in the Antilles. See GARCta-MARTINEZ, supra note 50, at 93.

53 See Charter of Autonomy, 1897, in 1 P.R. LAWS ANN., at 2 (2008).

64 See 1 José Trias Monge, Historia Constitucional de PUerto Rico 128 (Universidad de Puerto Rico 1980) [hereinafter 1 HISTORIA CONSTITUCIONAL].

65 Fernando Bayron-Toro, Elecciones y Partidos Políticos de Puerto Rico 107 (4th ed., Isla 1989) (1977).

56 It was an imperfect form of home rule, as the Spaniards retained the authority to appoint certain members of the upper chamber of the legislature and to set the eligibility requirements, which ensured that only the economically powerful classes would be allowed to run for office. The law required that candidates for office have "an annual income of four thousand pesos." See Charter of Autonomy, 1897, in 1 P.R. LAWS ANN., at 2-3 (2008). This was a lot in those days, when a teacher made 180 pesos a year and peasants made four-eights to seven-eights peso a day. See generally PEDRO MALAVET
} 
The Charter of Autonomy proved unacceptable to the more stridently pro-independence Puerto Ricans exiled in New York, some of whom encouraged the United States to invade. In 1892, these exiles had founded the Borinquen Club, a proindependence Puerto Rican group. After autonomist leaders in Puerto Rico rejected their call for revolution against Spain, officers of the club, which by then had changed its name to the Puerto Rico Section, met with Senator Henry Cabot Lodge in 1898 to ask the "United States government for help in evicting Spain from Puerto Rico."58 The pro-independence puertorriqueñas/os in New York even provided interpreters and scouts for the U.S. Army. To be sure, many believed that the United States would quickly give Puerto Rico independence after the invasion, as it did with Cuba. What they clearly underestimated in both Puerto Rico and Cuba was how disruptive "America's" imperial dreams would be for both islands. ${ }^{59} \mathrm{In} \mathrm{Ju}$ ly 1898, the americanos invaded, and the Autonomist experiment ended before Puerto Rico had a real chance, however limited, to rule itself.

Soon after the change in sovereignty, the former Pure and Orthodox Party became the pro-statehood Partido Republicano Puertorriqueño (Puerto Rican Republican Party). The party's organizers, which included José Celso Barbosa and Manuel F. Rossy, described their goals as "the definitive and sincere annexation of Puerto Rico to the United States. Declaration of organized territory for Puerto Rico, as a prelude thereafter to become a State of the Federal Union." 60 They favored accelerat-

VEGA, Historia de LA CANCIÓN POPULAR EN PUERTO Rico (1493-1898), at 293, 351, 448-49, 505-08 (1992). On the monetary units in Spanish times, see FERNANDO PICo, HISTORIA GENERAL DE PUERTO RICO 9 (1986).

57 BAYRON-TORO, supra note 55, at 129-39.

68 See WAGENHEIM, supra note 51, at 198-99.

59 Wagenheim notes, however, that Independence Leader Ramón Emeterio Betances, exiled in France, warned that "if the Puerto Ricans don't act fast after the Americans invade, the island will be an American colony forever." See WAGENHEIM, supra note 51 , at 200 (footnotes omitted).

60 Manifiesto de los dirigentes de la agrupación de los puros ortodoxos dirigido al país invitando a la formación del partido republicano puertorriqueño, April 19, 1899, in PUERTo Rico: Cien AÑos DE LUCHA POLítica vol. 1-1, 259-62 (Reece B. BothwellGonzález, ed., 1979) [hereinafter Manifiesto] (translation by the author). 
ing the Americanization project (the process of educating the Puerto Ricans in English to become "Americans"), which, they hoped, would lead to statehood. Accordingly, in their original political manifesto, they supported English as the language of instruction, "in order to put the country ["el país" (sic), referring to Puerto Rico] in conditions more favorable soon to become a new State of the Federation."61

Luis Muñoz-Rivera continued to lead the Autonomist/Liberal Party, which also was undergoing a transformation after the invasion and became the Partido Federal Puertorriqueño (Puerto Rican Federal Party) in October 1899. Perhaps surprisingly, the party's first official program, or platform, supported the immediate grant of territorial status to Puerto Rico and eventual statehood. ${ }^{62}$ But it also favored the absolute autonomy of the island's municipal governments to handle what the party called asuntos locales (local matters), especially education. ${ }^{63}$ This put them in direct conflict with the U.S. administrators and with the Republican Party. On October 26, 1900, an editorial in La Democracia, the newspaper published by the party and edited by Muñoz-Rivera, criticized the U.S. administrators of Puerto Rico and the Republican Party and its political thugs. ${ }^{64}$ The editorial ended with a call for withdrawal

\footnotetext{
61 Id. at 261 (translation by the author).

62 Programa del Partido Federal, 1 de octobre de 1899, in PUerto RICO: Cien AÑos DE LUCHA PolfTiCA vol. 1-1, 271-72 (Reece B. Bothwell-González, ed., 1979) [hereinafter Programa]. In February 1904, the Federal Party dissolved itself and was reconstituted as the Partido Unión de Puerto Rico (Union Party of Puerto Rico). The party again included among its principal leaders the autonomist Luis Muñoz-Rivera, the Autonomist Party founder and now independence leader Rosendo Matienzo-Cintrón, and another prominent independence supporter, José de Diego. Again displaying the colonial political pragmatism recognizing strength in numbers, the party also included statehood supporters. Its name was specifically chosen to describe the intent to unify the party members' diverse political views regarding status. The official minutes of the convention can be found in PUERTO RICO: CIEN AÑOS DE LUCHA POLfTICA vol. 1-1, 28285 (Reece B. Bothwell-González, ed., 1979).

${ }_{33}$ Item 6 in their official "program." Programa, supra note 62, at 271-72.

64 "El Retraimiento," La Democracia, October 26, 1900, in PUERTo RICO: CIEN AÑos DE LUCHA POLfTICA vol. 1-1, 273-74 (Reece B. Bothwell-González, ed., 1979).
} 
from the elections. Consequently, in 1900 the Federal Party boycotted the first election held under the U.S. regime. ${ }^{65}$

Native political thinking and organizing had developed greatly during the nineteenth century in Puerto Rico, so that when the United States arrived it found an elite of sophisticated politicians and parties ready to support, challenge, and oppose the new sovereign. The future of the Puerto Ricans, however, would not be determined in their local elections; it would be decided by their new sovereign, and initially, by the U.S. Supreme Court.

\section{THE UNITED STATES IN 1901: IN THE AFTERGLOW OF THE SPANISH-AMERICAN WAR}

Victory in the Spanish-American War left the United States in effective control of its new island empire. Militarily, but more importantly legally and politically, the United States found itself at a crossroads. The Spanish-American War and the Downes ruling brought to an end the age of Northwest Ordinances and Jacksonian Manifest Destiny ${ }^{66}$ as the prevailing theory of territorial expansion of the United States, in favor of a new colonial paradigm. In the aftermath of the war and U.S. takeover of Puerto Rico, the Philippines, Guam and Cuba, the Supreme Court gave constitutional approval to the acquisition

65 For a discussion of the election results, BAYRON-TORO, supra note 55, at 115-16, 120-21.

66 By this I mean the phrage as it was first used by Democrats aligned with President Andrew Jackson, who favored the incorporation of the Oregon territories, Texas and the spoils of the Mexican-American War into the United States, eventually as states of the union. More generally, as it was used to justify expansion of the United States, again through statehood, from the Atlantic to the Pacific. I am not using it in the sense that mostly-Republican "expansionists" of the late 1890 s and early twentieth century used it, since I prefer the clarity and distinguishing ability of the imperialism discourse, especially as it occurred around the elections of 1896, 1900 and 1904. See generally JUIIUS W. PRATT, EXPANSIONISTS OF 1898: THE ACQUISITION OF HAWAII AND THE SPANISH ISLANDS 1-33 (3d ed., Quadrangle Books 1964) (1936) (chapter entitled The New Manifest Destiny contrasts territorial expansion of the early nineteenth century U.S., mostly associated with Democrats, with the late 19th Century overseas expansionism advocated mostly by the Republicans). See also ZIMMERMANN, supra note 9 , at 13 (noting that most politicians who favored it avoided the term "imperialism" and barely tolerated "expansionism"). 
and control of territory for the sake of legal, political and military control of the islands rather than for national territorial expansion, accompanied by "immigration and settlement" by persons who were already citizens of the United States, and acceptable American stock. ${ }^{67}$

Theodore Roosevelt called this "Americanism;" Henry Cabot Lodge labeled it the "large policy." But it was imperialism, which the principal architect of America's naval doctrine at the time, Alfred T. Mahan, labeled as such and defined as "the extension of national authority over alien communities.' This broader definition implies that a country does not have to own the territory of an alien community in order to exercise imperial authority over it."68 Mahan criticized the shortcomings of the Spanish, French and Dutch imperial projects, while expressing his admiration for the English empire; he disposed of the irony of the American War of Independence from Great Britain as follows: "Since she lost what is now the United States, Great Britain has become benevolent and beneficent to her colonies."69

Behind the political debate over territorial expansion was a professional debate over military doctrine. The one that prevailed deemed naval power the most important way to project military and political authority abroad, and this was seen as essential to being a strong player in international political and economic affairs, as well as the best way to ensure the security of the United States. No one influenced this thinking more in favor of the projection of naval power than Mahan, a graduate of the U.S. Naval Academy at Annapolis and commissioned naval officer. He became president of the Naval War College, reportedly much to the chagrin of Annapolis and Navy authorities, in 1886. It was there that he developed as a scholar familiar with naval history, and where he developed a new vision of American naval doctrine. This doctrine was driven by the need

67 See generally Balzac v. Porto Rico, 258 U.S. 298 (1922), discussed infra Part VI.

68 ZIMMERMANN, supra note 9 , at 13 .

69 ALFRed T. MAHAN, The Relations of the United States to their New Dependencies, in Lessons OF THE WAR WITH SPAIN, AND OTHER ARTICLES 241, 243 (Boston, Little, Brown, \& Co. 1899). 
to project American power abroad. It required a large navy, with large capital ships, a canal in Panama, and the ability to maintain naval coaling stations throughout the world, but most especially in the Atlantic and Pacific oceans. ${ }^{70}$ Mahan concluded that the "triumphs and the sufferings of the past months [referring to combat operations in the SpanishAmerican War] have drawn men's eyes to the necessity for increase of force, not merely to sustain over-sea dominion, but also to ensure timely use, in action, of the latent military and naval strength which the nation possesses."71 Mahan was clearly a good scholar and a prolific writer, and his books and magazine articles became highly influential in political circles in Washington. ${ }^{72}$ Two particularly important admirers were Massachusetts Senator Henry Cabot Lodge and future President Theodore Roosevelt. ${ }^{73}$

The war targeted the last Spanish island colonies in the Caribbean and Pacific oceans. In President William McKinley's instructions to the U.S. delegation that negotiated the Treaty of Paris, the only full territory that he ordered them to demand from the Spanish was the islands of Puerto Rico. ${ }^{74}$ Although

\footnotetext{
${ }^{70}$ See generally ZIMMERMANN, supra note 9, at 85-122 (chapter 3, referring to Mahan as a "pen-and-ink sailor").

71 MAHAN, supra note 69, at 251.

72 See, e.g., A. T. Mahan, Some Neglected Aspects of War (Little, Brown Co. 1907), reprinted as UNILATERAL FORCE IN INTERNATIONAL RELATIONS (Garland 1972). Mahan's best-known work is THE INFLUENCE OF SEA POWER UPON HISTORY, 1660-1783 (12th ed., Boston, Little, Brown, \& Co. 1890). He also published extensively in magazines of the time. In his preface to another of his more important books, THE INTEREST OF AMERICA IN Sea PowER, PResent AND FUTURE, he stated: "The thanks of the author are expressed to the proprietors of the 'Atlantic Monthly,' of the 'Forum,' of the 'North American Review,' and of 'Harper's New Monthly Magazine,' who have kindly permitted the republication of the articles originally contributed to their pages." Alfred T. Mahan, Preface to The InTerest of America In Sea Power, Present AND FUTURE (Books for Libraries 1970) (1897). Both books are available in electronic form, at RIA PRESS CLASSIC BOOKS, http://www.riapress.com/riapress/index.lasso (last visited Mar. 15, 2010).

73 Mahan and Roosevelt met at a critical time. In 1887, Mahan invited Roosevelt to lecture at the War College on the War of 1812, which Roosevelt had studied while a student at Harvard. See ZIMmERMANN, supra note 9, at 92.

74 Instructions of the President to the United States Peace Commissioners, in Papers Relating to THE Treaty WITH Spain, S. Doc. No. 148, at 3.4 (1901). These papers initially were secret, but on February 5, 1901, the Senate lifted the "injunction
} 
the islands were important to the United States for military and economic reasons, their principal attraction was their strategic location when the Spanish-American War broke out. Indeed, the acquisition of Puerto Rico was contemplated from the very conception of the new "American empire" by two of its principal architects:

Assistant Secretary of the Navy Theodore Roosevelt, in a personal letter to Senator Henry Cabot Lodge, wrote: “. . . do not make peace until we get Porto Rico." Lodge replied: "Porto Rico is not forgotten and we mean to have it. Unless I am utterly ... mistaken, the administration is now fully committed to the large policy that we both desire."75

The strategic importance of Puerto Rico, correctly spelled, was noted and explained by Mahan in his work Lessons of the War with Spain, published in $1899 .{ }^{76}$ Mahan sums up the "military importance of Puerto Rico" as follows:

Puerto Rico, considered militarily, is to Cuba, to the future Isthmian canal, and to our Pacific coast, what Malta is, or may be, to Egypt and the beyond; and there is for us the like necessity to hold and strengthen the one, in its entirety and in its immediate surroundings, that there is for Great Britain to hold the other for the security of her position in Egypt, for her use of the Suez Canal, and for the control of the route to India. ... It would be very difficult for a transatlantic state to maintain operations in the western Caribbean with a United States fleet based upon Puerto Rico and the adjacent islands . .. [provided that island bases be accompanied by] adequate naval strength, without which no maritime position possesses value. ${ }^{77}$

of secrecy" and ordered the publication of three thousand volumes. Id. at 1. I state "full" territory because the U.S. did demand the cession of individual islands in the Ladrones and Philippine archipelagoes. Id. at 4, 7 (Guam in the Ladrones and Luzón in the Philippines).

75 The PUerto Ricans: A DocumentaRY History 89 (Kal Wagenheim and Olga Jiménez de Wagenheim eds., 4th ed. 2008) (emphasis added).

76 MAHAN, supra note 69.

77 Id. at 29-30. 
The war itself began after an ultimatum of sorts. On April 19,1898 , the U.S. Congress passed a joint resolution authorizing the president to use force if Spain "failed to pacify Cuba."78 On April 25, 1898, Congress declared war, retroactive to April 21,1898 , because on that date the U.S. warship Nashville had captured the Spanish ship Buenaventura. ${ }^{79}$ U.S. troops landed in Guánica, Puerto Rico, on July 25, 1898, while a naval force blockaded San Juan harbor. ${ }^{80}$ Although the campaign cannot be described as long or especially bloody, young men on both sides died and those who lived did so in fear. In his diary, a Puerto Rican-born gunnery officer in the Spanish army recounted the agonizing wait to be attacked in San Juan, when they already knew that U.S. troops had landed in the south and were marching north. They also were well aware of the presence of American warships offshore. Indeed, the wait proved too stressful for two of the gunnery officer's comrades, who attempted suicide. One of the U.S. soldiers, the poet Carl Sandburg, recounts his own deep fear of being attacked during the first night after his unit landed in Guánica. The only shots he heard, however, were fired by a unit from Illinois that apparently panicked during the night, firing so wildly that they hit the transport carrying the task force commander, several Red Cross nurses, and, presumably, fellow soldiers. ${ }^{81}$

The Spanish forces in Puerto Rico did not put up much of a fight. The guns of San Juan had not been fired in hostilities since they repelled the British invasion in 1797, and they had not been upgraded since then. The United States quickly cap-

78 President William McKinley signed the resolution on April 20. On April 21, the U.S. ambassador to Spain delivered an ultimatum to the Spanish government, giving it until noon on April 23, 1898, to pacify Cuba or leave. ANGEL RIVERO, CRÓNICA DE LA GUERRA HISPANOAMERICANA EN PUERTO RICO 18-24 (1971).

79 Id.

80 Rivero provides a critical analysis of the campaign and the tactics in his book, Crónica de la GuerRa Hispanoamericana EN PUERTO Rico on pages 522-23. RIVERO, supra note 78, 522-23.

81 THE PUERTO RICANS, supra note 75, at 96-97, 99-103. Among the U.S. troops that landed in Guánica was the poet Carl Sandburg. His account of the landing and the Puerto Rico campaign can be found in his autobiography. See generally CARL SANDBURG, ALWAYS THE Young STRANGERS (1953). The excerpts referring to the Puerto Rico campaign are quoted in THE PUERTO RICANS, supra note 75, at 96-98. 
tured the island. U.S. forces took Ponce, the largest city in the South of the island, on July 28, without firing a shot. On this date, Major General Nelson Miles issued a proclamation announcing:

To the inhabitants of Puerto Rico: In the prosecution of the war against the Kingdom of Spain by the people of the United States, in the cause of liberty, justice, and humanity, its military forces have come to occupy the Island of Porto Rico. . . . They bring you the fostering arm of a nation of free people, whose greatest power is in its justice and humanity to all those living within its folds.

The chief object of the American military forces will be to overthrow the armed authority of Spain and to give to the people of your beautiful island the largest measure of liberty consistent with this military occupation. ... [We have] come to bring protection, not only to yourselves but to your property, to promote your prosperity and bestow upon you the immunities and blessings of the liberal institutions of our government....82

In the Puerto Rico campaign, 17 Spanish soldiers were killed, 88 were wounded, and 324 were taken prisoner. For the United States, three soldiers were killed and forty were wounded, mostly by Puerto Rican irregular troops..$^{83}$

By August 12, 1898, the United States had ended its military operations in Puerto Rico, and on September 14, 1898, most of the remaining Spanish troops left the island. October 18 was the final day for the official surrender of San Juan to the U.S. troops, and the last few Spanish soldiers sailed aboard the warship Montevideo on October 23.84 The second colony had begun.

The Treaty of Paris, signed on December 10, 1898, approved by the U.S. Senate, and ratified by the president in

\footnotetext{
82 RAYMOND CARR, PUERTO RICO: A COLONIAL EXPERIMENT 31 (1984).

83 HÉCTOR ANDRÉS NEGRONI, HISTORIA MIIITAR DE PUERTO RICO 340 ([Spain]: Sociedad Estatal Quinto Centenario, 1992); CARR, supra note 82, at 28.

84 THE PUERTO RICANS, supra note 75, at 102-03.
} 
1899 , officially ended the Spanish-American War, with the island of Puerto Rico as the United States' prize. ${ }^{85}$

The national election of November 1900-won by "Imperialist" McKinley over "anti-Imperialist" William Jennings Bryan-was preceded by a heated political debate over what to do with the new territorial possessions. The Democratic Party platform denounced Republican "imperialism" and "militarism":

We declare again that all governments instituted among men derive their just powers from the consent of the governed; that any government not based upon the consent of the governed is a tyranny; and that to impose upon any people a government of force is to substitute the methods of imperialism for those of a republic.

We hold that the Constitution follows the flag, and denounce the doctrine that an Executive or Congress deriving their existence and their powers from the Constitution can exercise lawful authority beyond it or in violation of it. We assert that no nation can long endure half republic and half empire, and we warn the American people that imperialism abroad will lead quickly and inevitably to despotism at home.

We oppose militarism. It means conquest abroad and intimidation and oppression at home. ... We denounce it as unAmerican, un-Democratic, and un-Republican, and as a subversion of the ancient and fixed principles of a free people. ${ }^{86}$

The Republicans were clearly happy with the results of the Spanish-American War and embraced the notion of territorial

85 The official title is the "Treaty of Peace between the United States of America and the Kingdom of Spain." See Treaty of Paris, 1898, in 1 P.R. LAWS ANN., at 16 (2008). See also PEREA ET AL., supra note 5, at 327. Article II of the Treaty reads: "Spain cedes to the United States the island of Porto Rico and other islands now under Spanish sovereignty in the West Indies, and the island of Guam in the Marianas or Ladrones." PeREA ET AL., supra note 5, at 327. The editors of the Puerto Rican legal collection changed the references to "Porto Rico" included in the original English to "Puerto Rico." See 1 P.R. LAWS ANN., at 17.

86 Democratic Party Platform of 1900: July 4, 1900, The AMERICAN PREsidency PROJECT, http://www.presidency.ucsb.edw/ws/?pid=29587 (last visited Mar. 15, 2010). 
expansion. Their platform hailed the acquisition of American Samoa, favored the annexation of Hawaii, "home rule for, and the early admission to statehood of the Territories of New Mexico, Arizona, and Oklahoma." 87 But President McKinley and many in his party bristled at the Democrats' charge that his policies were imperialist and militaristic. The Republican platform generally defended the Spanish-American War and justified it as "liberation" of the island peoples:

In accepting by the Treaty of Paris the just responsibility of our victories in the Spanish war, the President and the Senate won the undoubted approval of the American people. No other course was possible than to destroy Spain's sovereignty throughout the West Indies and in the Philippine Islands. That course created our responsibility before the world, and with the unorganized population whom our intervention had freed from Spain, to provide for the maintenance of law and order, and for the establishment of good government and for the performance of international obligations. Our authority could not be less than our responsibility; and wherever sovereign rights were extended it became the high duty of the Government to maintain its authority, to put down armed insurrection and to confer the blessings of liberty and civilization upon all the rescued peoples. ${ }^{88}$

The President and candidate for reelection had to express his views in more detail in his acceptance of the nomination and his campaign speeches because the platform, despite highlevel discussions on the subject, failed to include already approved plank language explaining the Republican position on "[t]he constitutional relationship of the new possessions-not yet decided by the Supreme Court, and an inevitable campaign issue." 89 McKinley argued that it was up to Congress to decide the status of the island territories, while emphasizing that our intentions towards them were benevolent:

87 Republican Party Platform of 1900: June 19, 1900, THE AMERICAN PRESIDENCY PROJECT, http://www.presidency.ucsb.edu/ws/?pid=29630 (last visited Mar. 15, 2010).

88 Id.

89 LEECH, supra note 40, at 542. See also ZIMMERMANN, supra note 9, at 393 (noting that "Bryan made 'imperialism' the primary issue of his campaign"). 
We reassert the early principle of the Republican Party, sustained by unbroken judicial precedents, that the Representatives of the people in Congress assembled have full legislative power over territory belonging to the United States, subject to the fundamental safeguards of liberty, justice, and personal rights, and are vested with ample authority to act "for the highest interests of our Nation and the people intrusted to its care." This doctrine, first proclaimed in the cause of freedom, will never be used as a weapon for oppression. I am glad to be assured by you that what we have done in the Far East has the approval of the country.

The Republican Party was dedicated to freedom forty-four years ago. It has been the party of liberty and emancipation from that hour; not of profession, but of performance. It broke the shackles of 4,000,000 slaves and made them free, and to the party of Lincoln has come another supreme opportunity, which it has bravely met in the liberation of $10,000,000$ of the human family from the yoke of imperialism. ${ }^{90}$

McKinley was attempting to remind the nation of the debate at the time of Scott v. Sanford, discussed further in Part VI below, when the Republicans had argued that not all provisions of the Constitution should apply in the territories, in order to prevent the application therein of the constitutional language intended to protect the obscenity of slavery. ${ }^{91}$ But the Democrats pointed out that slavery was gone, and we were now faced with a new island empire.

On the night of November 6,1900, the Republicans won an overwhelming victory, earning 292 of 447 electoral votes and a majority of the popular vote. ${ }^{92}$ Between the time of his reelection and his assassination at the end of 1901, McKinley finished the takeover of the island territories, including, though

90 William McKinley, Address Accepting the Republican Presidential Nomination: July 12, 1900, THE AMERICAN PRESIDENCY PROJECT, http://www.presidency.ucsb.edu/ ws/?pid=76197 (last visited Mar. 15, 2010).

91 See infra notes 175-77 and accompanying text.

92 LEECH, supra note 40, at 559. 
somewhat reluctantly, the Philippines. ${ }^{93}$ Controlling and governing the new territorial possessions were major priorities of McKinley's administration starting in late 1898. His last three State of the Union Addresses, delivered, respectively, in December of 1898,1899 and 1900 , were principally focused on the results of the Spanish-American War and the affairs of the new insular possessions. ${ }^{94}$ The insurgency in the Philippines was the primary topic of discussion, the development of home rule for Puerto Rico, and the transition to a "free" Cuban constitution were the other major topics regarding the territories covered by the President in trying to set executive and congressional priorities. ${ }^{95}$

Between September 1898 and April 12, 1900, Puerto Rico was under military rule supervised by the War Department.96 In the fall of 1900, President McKinley and his administration had a strong interest in the Supreme Court cases that would define our constitutional authority over the newly conquered territories.

99 ZIMMERMANN, supra note 9, at 316 (discussing McKinley as a reluctant imperialist, especially about the Philippines), 401-02 ("[O]n September 6, 1901, President McKinley was shot ... at the mammoth Pan-American Exposition in Buffalo. . . . and he died on September 14 [1901].").

94 See generally William McKinley, Second Annual Message: Dec. 5, 1898, ThE AMERICAN PRESIDENCY PROJECT, http://www.presidency.ucsb.edu/ws/?pid=29539 (last visited Mar. 15, 2010); William McKinley, Third Annual Message, Dec. 5, 1899, The AMERICAN PresidenCY ProJeCt, http://www.presidency.ucsb.edu/ws/?pid=29540 (last visited Mar. 15, 2010); William McKinley, Fourth Annual Message: Dec. 3, 1900, THE AMERICAN PRESIDENCY PROJECT, http://www.presidency.ucsb.edu/ws/?pid=29541 (last visited Mar. 15, 2010).

95 See id.

96 April 12, 1900, was the effective date of the first law passed by the U.S. Congress creating a civilian government for Puerto Rico. The law, known as the Foraker Act is discussed further infra notes 117-28 and accompanying text. On the period of military rule, see generally Raúl SERRANO GEYLS, DERECHO CONSTITUCIONAL DE ESTADOS UNIDOS Y PUERTO Rico 439-42 (1986); CARMEN RAMOS DE SANTIAGO, El GOBIERNO DE PUERTO RICO 55-60 (1976). See also CARR, supra note 82, at 32-33. The early period of American rule in Puerto Rico was a bit messy. See AMERICA's COLONY, supra note 1, at 57-60 (discussing the early period of American occupation). For an interesting description of the period, see LEIBOWIT, supra note 33, at 140-41. See also discussion infra note 108 and accompanying text. 


\section{MR. BIDWELl AND THE 576 BOXES OF ORANGES}

Downes v. Bidwell is the principal decision of the nine Insular Cases of the 1900 term..$^{97}$ Most of the lawsuits involved the collection of taxes and tariffs on Puerto Rican agricultural products brought to the United States. But the cases necessarily raised questions of the meaning of citizenship and how the American Constitution would be applied to the new island territories.

Taxes, crops and citizenship were important themes in Puerto Rico in 1901. The island was still reeling not so much from the Spanish-American War, as from the storm islanders call "San Ciriaco" (Saint Cyril), which hit Puerto Rico on Tuesday, August 8, 1899. This tropical cyclone "caused 3,369 deaths and more than 2,000 injuries; damages to property were estimated at more than thirty five million dollars. Crops and farms ... were devastated. . . . Hunger and disease were rampant."98 A popular seis, the music of Puerto Rican farm laborers of the

97 (1) Downes v. Bidwell, 182 U.S. 244, 287 (1901) (5-4 ruling; interpreting the first organic act passed by Congress to regulate Puerto Rico, ruled: "We are therefore of the opinion that the island of Porto Rico is a territory appurtenant and belonging to the United States, but not a part of the United States within the revenue clauses of the Constitution. . .."); (2) De Lima v. Bidwell, 182 U.S. 1 (1901) (5-4 ruling; as a result of the Treaty of Paris, Puerto Rico is an island territory not a foreign country within meaning of U.S. tariff laws); (3) Goetze v. United States, 182 U.S. 221 (1901); (4) Crossman v. United States, 182 U.S. 221, 222 (referred to as "the Hawaiian case"; resolved summarily with Goetze, citing De Lima as controlling: neither "Port Rico [nor] the Hawaiian islands were foreign countries within the meaning of the [U.S.] tariff law ..."); (5) Dooley v. United States, 182 U.S. 222, 235 (1901) (referred to as "Dooley I"; stating that after the Treaty of Paris, Puerto Rico was no longer subject to U.S. tariffs); (6) Armstrong v. United States, 182 U.S. 243, 244 (1901) (duties imposed after signing of Treaty of Paris not properly executed); (7) Huus v. New York \& Porto Rico Steamship Co., 182 U.S. 392 (1901) (unanimous decision holding that ship traveling from San Juan to New York engaged in domestic "coasting trade" under U.S. law); (8) Dooley v. United States, 183 U.S. 151 (1901) (referred to as "Dooley II"; 5-4 along the voting lines of Downes, ruled that Foraker Act taxes on Puerto Rican imports were constitutionally imposed); (9) The Diamond Rings, 183 U.S. 176 (1901) (referred to as "the Philippines case;" 5-4, with Brown again the deciding vote with Fuller, Harlan, Brewer, and Peckham in the majority citing De Lima that the Philippines by virtue of the Treaty of Paris ceased to be a "foreign country" for purposes of U.S. tariff laws; and Gray, White, Shiras, and McKenna in dissent).

98 Pedro Malavet Vega, De las Bandas al Trío Borinquen (1900-1927), at 36 37 (2002) (translation by the author) [hereinafter DE LAS BANDAS]. 
time, blamed American racism and taxes for the post-war and post-storm suffering of the Puerto Ricans. After bemoaning the loss of the coffee crop (one of the most important crops in Puerto Rico at the turn of the twentieth century), the verses blame the Americans: "I am, man, convinced/ that the bad situation/ does not depend on the cyclone/ as many have believed./ The Yanqui's fault has been/ that he hates us a lot, a lot;/ and if what I hear is true,/ when they collect the tax/ jhow dangerous this is!/ we are jreally bad off, Perucho!"99 The song goes on to blame the "absorbent [yanqui] race" for "not being able to take" the Puerto Ricans.

The Insular Cases were so important in their day that the filing of the briefs was widely reported, ${ }^{100}$ oral argument occurred over a period of ten days, and the resulting opinions occupy hundreds of pages and over two volumes of the U.S. Reports for the October Term of 1900 (numbers 182 and 183). In the midst of the litigation of the cases at the Supreme Court level, a fight erupted in the U.S. Senate over the nomination of Justice Harlan's son to be Attorney General of Puerto Rico. He was finally confirmed on May 21, 1901, just before the Insular Cases were decided with his father as one of the dissenters against the administration position. ${ }^{101}$ Soon after the cases were decided, the 56th Congress ordered a reprinting of the parties' written briefs and transcription of oral arguments into

99 DE LAS BANDAS, supra note 98, at 37. Malavet Vega notes that the song was published in the labor newspaper El Pan del Pobre (the Poor Man's Bread), on $25 \mathrm{Au}$ gust 1901. Id. at 115 n.13. The original Spanish lyrics are: Estoy, chico, convencido/ que la mala situación/ no depende del ciclón/ como muchos han creído./ La culpa del yanqui ha sido/ que nos odia mucho, mucho/ y si es cierto lo que escucho,/ cuando cobren el impuesto,/ iqué peligroso está esto!/ iqué mal estamos, Perucho! Id. at 37.

100 See, e.g., Held Over By Supreme Court: Cases Involving Question Whether Porto Rico and Philippines Are Part of United States Postponed, N.Y. Times, Nov. 13, 1900 , at 8.

101 See Fight on Harlan Nomination: Senators Foraker and Pettigrew Get Into a Heated Argument-Confirmation Again Delayed, N.Y. TIMES, Jan. 17, 1901, at 5 (soon after oral argument was heard on Downes); see also Acts on Harlan Nomination, N.Y. TIMES, Jan. 22, 1901, at 7 ("The Senate in executive session to-day confirmed the nomination of James S. Harlan to be Attorney General of Porto Rico. The final vote was reached after a discussion of more than two hours' duration, and when announced stood 43 to 21 in favor of confirmation."). 
a volume which the Supreme Court reports note-with some sense of awe- "amounted to 1075 pages."102

May 27, 1901 was to be the last day of the term, but the reading of the opinions in the Insular Cases took about five hours, forcing the Court to reconvene the next day. ${ }^{103}$ The opinions were read in the "Old Senate Chamber," where the Court held sessions between 1860 and 1935, when its current building was completed. ${ }^{104}$ "The small courtroom was crowded to repletion throughout the day, prominent government officials and many attorneys being present, and the proceedings were followed from start to finish with keen interest."105 The Washington Post and the New York Times ran front-page articles reporting on the decisions, noting that one of the government dignitaries was Secretary of War Elihu Root. ${ }^{106}$

Elihu Root was a successful New York corporate lawyer when he was selected for the position of Secretary of War by President McKinley, not because of his non-existent military experience, but rather because he was a lawyer. His initial reaction to receiving the job offer over the "newfangled telephone" was to reply: "Thank the President for me . . but say that it is quite absurd. I know nothing about war, I know nothing about the army." 107 The reply he received illustrates why he is such an important figure in understanding the Insular Cases:

President McKinley directs me to say that he is not looking for any one who knows anything about war or for any one who

102 De Lima v. Bidwell, 182 U.S. 1, 3 (1901); 56th Congress, H.R. 72; THE INSULAR CASES, Comprising THe Records, BRIEFS, AND ARguments OF CoUnSEL IN THE INSULAR CASES OF THE OCTOBER TERM, 1900, IN THE SUPREME COURT OF THE UNITED STATES, INCLUDING THE APPENDIXES THERETO (Gov't Printing Office 1901).

${ }_{103}$ Special, Court Decides Insular Cases: Holds that the Foraker Act Is Constitutional, N.Y. TIMES, May 28, 1901, at 1.

104 History of the Court: Home of the Court, The SUPREMe CoURT Historical SOCIETY, http://www.supremecourthistory.org/history/supremecourthistory_history_ homes.htm (last visited Mar. 15, 2010).

105 Court Decides Insular Cases: Holds that the Foraker Act Is Constitutional, supra note 103, at A1.

106 See The Status of Our Insular Possessions, WASH. POST, May 28, 1901, at 1; see also supra note 103 and accompanying text.

107 LEECH, supra note 40, at 379. 
knows anything about the army; he has got to have a lawyer to direct the government of these Spanish islands, and you are the lawyer he wants. ${ }^{108}$

The Insular Possessions were regulated through the War Department between 1898 and 1934, when that responsibility was shifted to the Department of the Interior. ${ }^{109}$ This Secretary of War was therefore an interested and quite knowledgeable listener as the opinions were read. ${ }^{110}$

In the first opinion to be read, De Lima v. Bidwell, the U.S. Supreme Court ruled that for the purpose of imposing import tariffs in the United States, Puerto Rico was not a foreign country but rather a U.S. territory. ${ }^{111}$ Specifically, Justice Brown-speaking for himself, Chief Justice Fuller, Justices Harlan, Brewer and Peckham-wrote that "by the ratification

108 Id. See also ZIMMERMANN, supra note 9, at 147-48 (recounting the same story).

109 Between 1898 and 1934, Puerto Rico was governed through the War Department. That responsibility was shifted to the Department of the Interior, effective May 1934, where it remained until 1952. See José TRIAS MONGE, PUERTO RICO: THE TRIALS OF THE OLDEST COLONY IN THE WORLD 58 (1997) (this text incorrectly gives 1933 as the date, which is probably a typographical error since in his more detailed collection, and in his original source, it indicates 1934); 2 JOsE TRfAS MONGE, HISTORIA CONSTITUCIONAL DE PUERTO RICO 206-14 (1981) (discussing the transfer of authority to the Department of the Interior).

110 His attendance prompted the exchange discussed supra note 1. See 1 PHILIP C. JESSUP, ELIHU ROOT, 1845-1090, at 348 (Dodd, Mead \& Co. 1938) (referring to the famous cite quoting DUNN, supra note 1, at 257). This book also contains an interesting analysis of the correspondence and discussion between Root, then Secretary of State John Hay and President McKinley on the subject of the territories, concluding that "Root did not trust Congress to do an efficient job in mapping out a form of colonial government [for the insular possessions]." Id. at 348. Shortly before his assassination, McKinley expressed his intention to create a bureau in the Department of State to deal with the insular possessions. On September, 14, 1901, Root wrote Hay to express his support for the "Bureau of Insular Affairs" at the Department of State because supervision of the insular governments "can go where it belongs under civil control in the nearest approach we can make to a Department of Colonial Affairs." Id. at 350. Root became Secretary of State in the administration of Theodore Roosevelt, and it is in that capacity that he visited Puerto Rico starting on July 8, 1906, during his "South American Trip." Id. at 468-92 (detailing and contextualizing this long voyage). He was entertained at the Governor's mansion, La Fortaleza, by the Puerto Rican Police band, directed by Francisco Verar. See DE LAS BANDAS, supra note 98 , at $65,81$.

111 De Lima v. Bidwell, 182 U.S. 1 (1901). The Court narrowly construed the question presented in the case: "This case raises the single question whether territory acquired by the United States by cession from a foreign power remains a 'foreign country' within the meaning of the tariff laws." Id. at 174. 
of the Treaty of Paris the island became territory of the United States, although not an organized territory in the technical sense of the word."112 Therefore, sugar from Puerto Rico was not "imported merchandise" under the general tariff laws of the United States, as amended by the Customs Administrative Act of $1890,{ }^{113}$ because the tariffs in those laws applied only to imports from foreign countries. Bidwell, the collector of taxes at the port of New York, lacked the authority to levy tariffs on Puerto Rican products under that law. Accordingly, "duties [on sugar imported from Puerto Rico] were illegally exacted, and . . . the plaintiffs [were] entitled to recover them back."114

But anticipating here in dissent what he would later join in concurring in Downes, Justice McKenna-speaking for himself and Justices White and Shiras-indicated that the status of Puerto Rico represented "a relation to the United States between that of being a foreign country absolutely and of being domestic territory absolutely." 115 Where the majority had seen only the categories of (a) foreign countries and (b) domestic territories, the dissenters saw (a) "foreign countr[ies]," such as Spain and its possessions, (b) "domestic territory[,] as New York now is," and (c) "[b]etween these extremes there are other relations, and that Porto Rico occupied one of them."116 The majority does make the brief descriptive distinction between U.S. territories that are "organized" and those that are "not organized." But, as their votes in Downes make clear, four of the five members of that majority (Fuller, Harlan, Brewer and Peckham) did not intend that distinction to have constitutional significance in determining the civil rights of the territorial

112 Id. at 196 (emphasis added). Justice Brown delivered the opinion of the Court, which was joined by Chief Justice Fuller, and Justices Harlan, Brewer and Peckham.

113 Ch. 407, 26 Stat. 131 (discussed by the Court in De Lima, 182 U.S. at 175).

114 De Lima, 182 U.S. at 200. I have ignored other issues addressed by the Court in this removal action, especially the jurisdictional and remedy questions, because they are not pertinent here. But anyone interested in the statutory limitations on the Court's jurisdiction or on remedies available for governmental misapplication of statutes will find parts of the majority opinion of interest.

115 Id. at 220 (McKenna, J., dissenting).

116 Id. at 200-01. 
citizens or the constitutional limitations on the power of congress and president to rule them.

De Lima was immediately eclipsed by the reading of the Downes decision, because it interpreted the Foraker Act of April 12, 1900, making Downes the most important of the Insular Cases. The facts in De Lima occurred in the fall of 1899, before passage of the Foraker Act. ${ }^{117}$ The Foraker Act, in providing for a government for Puerto Rico, turned it into an "organized" territory, i.e., one that is subject to a congressional organic statute. Therefore, the Supreme Court would be faced with the question of what constitutional rights are applicable in any territory subject to U.S. sovereignty that was not yet a state.

The Act-named after the very powerful Republican Senator from Ohio, Joseph Benson Foraker-authorized a U.S.appointed civilian government to be established on the island, and its chief executive, the governor, would be named by the president of the United States. ${ }^{118}$ The president also appointed the members of the cabinet, known as the Executive Council, who also acted as the upper legislative house. The lower house of thirty-five delegates was elected by the people of Puerto Rico. The chief justice and associate justices of the island's supreme court were to be appointed by the president of the United States. The Act created the Federal District Court for Puerto Rico. ${ }^{119}$ This regime lasted until 1917 when it was replaced by the Jones Act, which led to the Balzac decision discussed in the next section. ${ }^{120}$

During discussion of the Foraker Bill, the U.S. Senate changed references to "Puerto Rico" contained in the original

117 Id. at 2 (majority opinion).

118 See Foraker Act, ch. 191, 31 Stat. 77 (1900), codified as amended in 48 U.S.C. (2006) (various sections), and in 1 P.R. LAWS ANN., at 24-48 (2008). See also 1 P.R. LAWS ANN., at 36-37.

119 See generally Foraker Act, in 1 P.R. LAWS ANN., at 33-34, 36-39, $42-44$ (2008). The Executive Council is argued to have been the most important element in the process of "Americanizing" Puerto Rico. See PEDro A. CABÁN, Constructing A Colonial PEOPle: PUERTO RICO AND THE UNITED STATES, 1898-1932, at 122-26 (1999).

120 See Jones Act, ch. 145, 39 Stat. 951, 953 (1917), and in 1 P.R. LAWS ANN., at 52 (2008). 
draft with "Porto Rico," and that denomination was used in the final proposal and was only changed by law in $1932 .{ }^{121} \mathrm{~A}$ defense of the new spelling of the island's name in the law strikes a modern reader as a concession to underachieving:

A Senate Committee has decided that "Porto Rico" is the proper spelling of our new island territory, and not "Puerto Rico," after the local and Spanish usage. The spelling adopted by the committee ought to prevail. It is the easiest and simplest form and in accordance with common-sense principles. Whenever an opportunity presents itself, as in this case, to choose between a phonetic form of spelling and an intricate or more involved form, the former ought always to be adopted. Silent letters and fantastic combinations in words impose a useless and wholly unnecessary tax upon the memory and intellect, and they ought to be ruled out of the English language as rapidly as possible. Life is too short and time too precious to be spent in trying to master the absurdities of the spelling book, which have no excuse for existence. ${ }^{122}$

Beyond the misspelling of Puerto Rico's name, the Senate made a more significant change: it removed from the draft of the Bill any reference to extending the United States Constitution to the territory of Puerto Rico.123 This sets up the legal question that would be resolved in Downes: does the Constitu-

\footnotetext{
121 Government of Puerto Rico, N.Y. TIMES, Jan. 28, 1900, at 4. See Act of 1932, ch. 190, 47 Stat. 158:

That from and after the passage of this resolution the island designated "Porto Rico" in the Act entitled "An Act to provide a civil government for Porto Rico, and for other purposes," approved March 2, 1917, as amended, shall be known and designated as "Puerto Rico." All laws, regulations, and public documents and records of the United States in which such island is designated or referred to under the name of "Porto Rico" shall be held to refer to such island under and by the name of "Puerto Rico."
}

See 48 U.S.C. § 731a (2006).

122 Leslie's Weekly, Common Sense in Spelling, N.Y. TTMES, Mar. 18, 1900, at 29.

123 The removed provision appears to mirror already-existing statutory language that extended the application of the Constitution to "organized" territories. See ch. 1, 18 Stat. 334 (1874) ("The Constitution and all laws of the United States which are not locally inapplicable shall have the same force and effect within all the organized Territories, and in every Territory hereafter organized as elsewhere within the United States."). 
tion automatically apply in a U.S. territory. The Senators' decision was explained thusly:

The change was made because of the opinion generally expressed by the members of the committee that our Constitution is not suited to the Puerto Rican people. The opinion was also quite general that the extension of the Constitution was not necessary. Some of the Senators expressed the opinion that the natives of the island were not yet prepared for jury trials. ${ }^{124}$

What started out as a bill to extend civil rights and government to Puerto Rico, and to include the island in the freetrade internal to the United States, became a much-simpler organic act to enable civilian government for the island. Republican protectionists scuttled the free trade provisions and substituted a tax. ${ }^{125}$ Therefore, the Foraker Act also imposed a tax of "fifteen per centum of the duties which are required to be levied, collected, and paid upon like articles of merchandise imported from foreign countries" on Puerto Rican imports into the United States. ${ }^{126}$

While the Republicans failed to include proposed language praising the law in their platform, ${ }^{127}$ the Democrats turned the Act into a major campaign issue in the election of 1900 . The Democratic platform-after declaring their view "that the Constitution follows the flag"-attacked the Foraker Act:

[W]e denounce the Porto Rican law, enacted by a Republican Congress against the protest and opposition of the Democratic minority, as a bold and open violation of the nation's organic law and a flagrant breach of the national good faith. It imposes upon the people of Porto Rico a government without their consent and taxation without representation. It dishonors the American people by repudiating a solemn pledge made in

124 Government of Puerto Rico, supra note 121, at 4.

125 LEECH, supra note 40, at 487-89 (detailing the development of the Bill in Congress).

126 See Foraker Act, ch. 191, 31 Stat. 77 (1900). This was a change from the originally proposed Bill, reportedly as a result of protests from and lobbying by sugar producers and citrus farmers. See LEECH, supra note 40, at 488.

127 See supra note 87. 
their behalf by the Commanding General of our Army, which the Porto Ricans welcomed to a peaceful and unresisted occupation of their land. It dooms to poverty and distress a people whose helplessness appeals with peculiar force to our justice and magnanimity. In this, the first act of its imperialistic programme, the Republican party seeks to commit the United States to a colonial policy, inconsistent with republican institutions and condemned by the Supreme Court in numerous decisions. ${ }^{128}$

President and presidential candidate McKinley explained the Republican position on constitutional authority over the territories as follows:

We reassert the early principle of the Republican Party, sustained by unbroken judicial precedents, that the Representatives of the people in Congress assembled have full legislative power over territory belonging to the United States, subject to the fundamental safeguards of liberty, justice, and personal rights, and are vested with ample authority to act "for the highest interests of our Nation and the people intrusted to its care." This doctrine, first proclaimed in the cause of freedom, will never be used as a weapon for oppression. ${ }^{129}$

With the respective arguments already articulated by the opposing sides in the political branches of government, a judicial decision would have to settle the matter. On November 20, 1900 , George R. Bidwell, the same collector of customs at the port of New York involved in De Lima, demanded \$659.35 in taxes:

[U]pon thirty-three (33) boxes of oranges . . . from the port of San Juan . . . and . . . upon 543 boxes of oranges, [also] the product of the island of Porto Rico, consigned to these plaintiffs ["Samuel B. Downes, doing business under the firm name of S.B. Downes \& Company,"] at the port of New York and brought thither from the port of Mayaguez in the said island

${ }^{128}$ Democratic Party Platform of 1900: July 4, 1900, supra note 86.

129 McKinley, supra note 90. 
of Porto Rico during the month of November, 1900, by the steamer Ponce .... 130

The plaintiffs paid under protest, got their oranges andrepresented by Coudert Brothers, ${ }^{131}$ the New York City law firm, with offices at 71 Broadway-filed their suit that same day! The complaint, which was verified under oath by Samuel B. Downes personally, alleged a case "arising under" the Constitution, specifically:

[T] he said oranges were not liable to duty, the same not having been imported from any foreign country within the meaning of any valid statute or executive order of the United States, but were merchandise which must, under and by virtue of the provisions of the Constitution of the United States in that regard, be admitted to free entry in any port of the United States. ${ }^{132}$

Procedurally, this was the period of the Evarts Act of 1891, during which the circuit courts lost their appellate jurisdiction to the newly-created courts of appeals, but retained their original trial jurisdiction. ${ }^{133}$ Additionally, this was not that long after the lower federal courts were first granted original jurisdiction over federal question complaints in the Judiciary Act of $1875,{ }^{134}$ and it predated the enactment of the Federal Rules of Civil Procedure in 1938. Therefore, rather than filing a Motion to Dismiss under Rule 12 of the current Federal Rules of Civil Procedure, United States Attorney for the Southern District of

\footnotetext{
130 See THE INSULAR CASES, supra note 102, at 723-24.

131 Paul Fuller was a partner at Coudert Brothers, which represented the private litigants in the most important Insular Cases, along with Frederic R. Coudert, Jr. He was born in 1856, orphaned of mother and abandoned by his father. He was raised by Charles Coudert and became a prominent attorney in the New York Bar. He helped to found Fordham Law School and was its dean. The Paul Fuller Memorial Children's Service Program: Coudert Brothers LLP Globalizes Pro Bono, The METRO. CorP. COUNSEL, Aug. 1, 2004, http://www.metrocorpcounsel.com/current.php?artType=view \&artMonth=August\&artYear=2004\&EntryNo=1474 (last visited Mar. 15, 2010).

132 See THE INSULAR CASES, supra note 102, at 724.

138 ERWIN CHEMERINSKY, FEDERAL JURISDICTION 22-23 (2d ed. 1994) (citing Evarts Act of 1891, ch. 517, 26 Stat. 826). "In 1911, the circuit courts were eliminated and their original trial jurisdiction transferred to the district courts." CHEMERINSKY, supra at 24 (citing Act of 1911, ch. 1, 36 Stat. 1087).

184 Ch. 137, 18 Stat. 470 (1875). See also ChEMERINSKY, supra note 133, at 222.
} 
New York Henry L. Burnett filed a demurrer arguing "[t]hat the complaint does not state facts sufficient to constitute a cause of action." 135 On November 30, 1900, Circuit Judge Henry Lacombe heard oral argument "at the post-office building, in the borough of Manhattan, in the city of New York" and ruled in favor of the defendant, ordering the complaint dismissed and awarding costs to the defendant. ${ }^{136}$ Judgment was entered dismissing the action and taxing costs in the amount of $\$ 16.30$ at 12:30 p.m. on December 1, 1900. ${ }^{137}$ Downes filed a writ of error-giving notice of the appeal-with the circuit court on December 5,1900 . Judge Lacombe officially allowed the matter to proceed, and clerk of the court John A. Shields certified a nineteen-page record for appeal on December 7, 1900, canceling a "ten-cent U.S. internal-revenue stamp." 138 The case was filed with the Supreme Court on December 11, 1900 and assigned case number 507. 139

Though the plaintiffs were clearly interested in the constitutional principle, the monetary amounts involved were not insubstantial. The Foraker Act had provided a salary of $\$ 8,000$ dollars a year for Puerto Rico's governor, and salaries between $\$ 3,000$ and $\$ 5,000$ for high officials including the justices of the Supreme Court. ${ }^{140}$ The justices of the United States Supreme Court earned $\$ 10,000$ a year in 1901 , and that salary had just been increased in 1900 after remaining at $\$ 6,000$ for forty years. ${ }^{141}$ Moreover, the salaries of the high officials were immense sums in the context of Puerto Rico. Just before the American invasion, a Puerto Rican teacher earned 180 pesosthe Spanish monetary unit-a year, and peasants earned foureights to seven-eights peso per day. ${ }^{142}$ Section 11 of the Foraker

135 The InSUlar CASES, supra note 102, at 725.

136 Id. at 725-26.

137 Id. at 726.

138 Id. at 721-22. The system of canceling stamps to pay court filing fees is still used in the local courts in Puerto Rico, where I am admitted to practice.

139 Id. at 729.

140 See Foraker Act, ch. 191, 31 Stat. 77, 85 (1900).

141 Richard A. Posner, The Federal Courts: Challenge and Reform 22 (1996) (citations omitted).

142 MALAVET VEGA, supra note 56, at 293, 351, 448-49, 505-8. On the monetary units in Spanish times, see PICO, supra note 56, at 9. 
Act provided for an exchange rate of sixty cents for every pe$s o,{ }^{143}$ and the first legislative assembly elected under the auspices of the Foraker Act provided minimum salaries of between thirty and fourty "dollars per school month, for each month of actual service" for teachers in Puerto Rico. ${ }^{144}$ Therefore, while we might today resent a constitutional doctrine that relegates Puerto Ricans and other territorial peoples of the United States to second-class citizenship for a few hundred dollars and 576 boxes of oranges, in $1900, \$ 659.35$ was a lot of money.

Justice Brown announced the result of the case, but the four concurring justices joined or issued separate opinions; therefore, in articulating his reasoning he wrote only for himself. ${ }^{145}$ The Court ruled:

that the Island of Porto Rico is a territory appurtenant and belonging to the United States, but not a part of the United States within the revenue clauses of the Constitution; that the Foraker act is constitutional, so far as it imposes [discriminatory] duties upon imports from such island [to the United States]. ${ }^{146}$

Despite its division, the majority rejected the argument that in matters of taxation, Congress could not treat the U.S. territory of Puerto Rico differently than a U.S. state; thus, Puerto Rican exports to the U.S. mainland were subject to duties not imposed on the products of the states. Therefore, import tariffs on oranges, sugar, or any other Puerto Rican product, were legitimately imposed by the U.S. Congress. ${ }^{147}$ Justice White's concurring opinion had the most votes, since it was

\footnotetext{
143 See Foraker Act, ch. 191, 31 Stat. 77, 80 (1900).

144 Id. at $\$ 16-18$. See also WILliam H. HUNT, ACTS AND ResOlves OF THE FirST Legislative AsSEMBLy OF PORTO Rico 34 (1901).

145 Downes v. Bidwell, 182 U.S. 244, 247 (1901). The opinion states that "Mr. Justice Brown announced the conclusion and judgment of the court." Id.

146 Id. at 287. The Foraker Act required "the payment of ' 15 per centum of the duties which are required to be levied, collected, and paid upon like articles of merchandise imported from foreign countries" Id. at 248.

147 In other words, the equal taxation provision of the Constitution did not benefit Puerto Rico. Cf. U.S. ConST. art. I, § 8, cl. 1 ("The Congress shall have Power To lay and collect Taxes, Duties, Imposts and Excises, to pay the Debts and provide for the common Defence and general Welfare of the United States; but all Duties, Imposts and Excises shall be uniform throughout the United States").
} 
joined by Justices Shiras and McKenna, the same three who had subscribed McKenna's dissent in De Lima. Articulating what will eventually become the accepted doctrine, White found that Puerto Rico (and by analogy Guam and the Philippines) was an organized but unincorporated territory of the United States, that is, part of the United States under the "Territorial Clause"148 but subject to absolute congressional legislative authority under that provision and the "Necessary and Proper Clause" of the U.S. Constitution. ${ }^{149}$ Justice Gray, the final vote for the bare majority, issued a separate concurrence, like Brown speaking only for himself. ${ }^{150}$ The four dissenting justices-Chief Justice Fuller, Justices Harlan, Brewer and Peckham-joined a single dissenting opinion authored by Fuller, ${ }^{151}$ but Justice Harlan also issued a separate dissent. ${ }^{152}$ Justice Harlan's dissent has become better known and regarded over the years, just as Justice White's concurrence became the accepted constitutional doctrine.

For those who believed that territorial expansion along an imperialist/colonial model was a sound national policy, Justice Brown's obvious contradictions between his position in $\mathrm{De} \mathrm{Li}$ $m a$ and Downes were intellectually indefensible. Regardless of Brown's consistency issues, this seems rather unfair to the four other members of the De Lima majority-Chief Justice Fuller, Justices Harlan, Brewer and Peckham, the dissenters in Downes-and to the opinion they joined. The four dissenters in Downes express views that are perfectly consistent with their majority opinion in De Lima. De Lima, however, was limited to its facts, because the then existing state of the law was superseded by the Foraker Act and by Downes, making the latter the dominant decision. Unfortunately for the dissenters, when judging Downes, Justice White's plurality became the favorite because it articulates the pro-empire view in an intellectually-

\footnotetext{
148 See U.S. ConST. art. IV, § 3, cl. 2.

149 U.S. CoNST. art. I, § 8, cl. 18.

150 Downes v. Bidwell, 182 U.S. 244, 345 (1901) (Gray, J., concurring).

161 Id. at 347 (Fuller, J., dissenting).

162 Id. at 375 (Harlan, J., dissenting).
} 
defensible manner. For example, the New York Times editorialized soon after the cases:

The De Lima case was a stumbling block for Justice Brown. By asserting in that case the principle that cession and possession made Porto Rico a part of the territory of the United States he invalidated much of the reasoning by which he reached, in the Downes case, the conclusion that for purposes of tariff legislation the island is not territory of the United States within the prohibition which the Constitution lays upon Congress respecting uniform taxes. In making this assertion we are supported by the high authority of Horace Gray and by the clearly reasoned opinion of Justice White, speaking for himself and Justices Shiras and McKenna, concurring in the view that the Porto Rican tariff is not repugnant to the Constitution, but reaching that conclusion by a process of reasoning and interpretation solidly based upon the historical practice and judicial sanctions of a century of territorial increase. It would have been better for the reputation of the Supreme Court had the task of writing its opinion in the controlling case of Downes been committed to Justice White. ${ }^{153}$

The New York Times editorial also noted another strength in Justice White's opinion: it overruled Scott v. Sanford, which the newspaper celebrated with the following editorial comment: "The ex proprio vigore doctrine of constitutional application as expounded by Calhoun in the interest of the slave power is destroyed forever."154

Some of the most prominent legal thinkers of the time took positions on the matters at issue in the Insular Cases, most notably in early issues of the Harvard Law Review and the Yale Law Journal. Indeed, the early volumes of those two jour-

153 Editorial, The Court and the Opinions, N.Y. Times, May 29, 1901, at 8.

154 Id. See discussion infra note 177 and accompanying text. The "Calhoun" named in the editorial is John Calmore Calhoun, most famous as the staunchly racist, proslavery Senator from South Carolina from 1832 until his death in 1850 (although he left the Senate to serve as Secretary of State in 1845). Calhoun had served in the House of Representatives, as Secretary of War and as Vice-President of the United States under Presidents John Quincy Adams and Andrew Jackson. He was the first person to resign the vice-presidency, which he did in order to run for the Senate in 1832. 
nals are full of articles debating the legal status of the new island territories-four articles in volume twelve and three in volume thirteen of the Harvard journal, and four in volume eight of the Yale journal-for the years 1898-1899. For example, Harvard Law School Dean Langdell supported unfettered congressional authority, ${ }^{155}$ as did Simeon E. Baldwin. ${ }^{156}$ Recognizing that the executive was in effective control of the conquered territories, Baldwin addressed executive powers, and, referring specifically to the power of the presidency, he wrote: "[A]ll honest men, not blinded by party passion, felt that the President held great constitutional functions, which made him, in his sphere, little short of the dictator of the Republic."157 More generally, this legal scholarship interpreted the Territorial Clause along three lines: (1) absolute congressional power totally unfettered by other constitutional constraints; (2) almost completely unfettered congressional authority but limited by fundamental constitutional guarantees; and (3) the "Constitution Follows the Flag," meaning that all constitutional guarantees and constraints on congressional power apply in the territories. 158

Downes effectively established the distinction between different types of "domestic territories," but now in concurrence rather than in dissent, with White labeling them incorporated and unincorporated territories. This was important because at the time the United States already had other territories, most of which were then believed to be on their way to statehood.

155 See C.C. Langdell, The Status of Our New Territories, 12 HARV. L. REv. 365, 379-92 (1899) (detailing how, in the author's view, most provisions limiting congressional authority to legislate did not apply to the new territories).

156 See Simeon E. Baldwin, The People of the United States, 8 YALE L.J. 159, 159, 167 (1899) (arguing that the phrase "the People of the United States" in the preamble of the Constitution limited the applicability of the Constitution to citizens of the states); see also Simeon E. Baldwin, The Constitutional Questions Incident to the Acquisition and Government by the United States of Island Territory, 12 HARV. L. REV. 393 (1899) (upon approval of the Treaty of Paris by the U.S. Senate, authority to govern the territories would be transferred from the executive to the legislative branch).

167 Simeon E. Baldwin, Absolute Power, An American Institution, 7 YALE L.J. 1, 19 (1897).

158 Trias Monge provides a succinct analysis of the legal literature of the time. See 1 HISTORIA CONSTITUCIONAL, supra note 54, at 238. 
Indeed Arizona, New Mexico, Oklahoma, Alaska, and Hawaii would eventually become states of the union. The District of Columbia, as a special federal enclave, also fell within this discourse, but has not become a state. This made the arguments of absolute congressional authority unacceptable to scholars like Abott Lawrence Lowell. ${ }^{159}$ Puerto Rico in his view was a "part of" the United States but had not been "incorporated" into it. This was the perfect imperial compromise. We could control land and its people by making it domestic U.S. territory relative to other countries, but we were not bound to give to the people living in those territories the same rights enjoyed in the states of the union.

In his dissenting opinion, Justice John Marshall Harlan found the distinction less than compelling:

I am constrained to say that this idea of "incorporation" has some occult meaning which my mind does not apprehend. It is enveloped in some mystery which I am unable to unravel.

In my opinion Porto Rico became, at least after the ratification of the treaty with Spain, a part of and subject to the jurisdiction of the United States in respect of all its territory and people, and that Congress could not thereafter impose any duty, impost, or excise with respect to that island and its inhabitants, which departed from the rule of uniformity established by the Constitution. ${ }^{160}$

Most important, the majority, over the vigorous dissent of the four justices, gave to the U.S. Congress almost unfettered discretion to do with Puerto Rico what it wanted. In the dissenting opinion written by Chief Justice Melville W. Fuller, joined by Justices Harlan, David J. Brewer, and Rufus W. Peckham, the minority called for constitutional values to prevail over the desire for empire:

They may not, indeed, have deliberately considered a triumphal progress of the nation, as such, around the earth, but, as [Chief Justice John] Marshall wrote: "It is not enough to

\footnotetext{
159 See Abott Lawrence Lowell, The Status of our New Possessions, 13 HARV. L. REV. 155 (1899).

160 Downes v. Bidwell, 182 U.S. 244, 391 (1901) (Harlan, J. dissenting).
} 
say that this particular case was not in the mind of the convention when the article was framed, nor of the American people when it was adopted. It is necessary to go farther, and to say that, had this particular case been suggested, the language would have been so varied as to exclude it, or it would have been made a special exception."

This cannot be said, and, on the contrary, in order to the successful extension of our institutions, the reasonable presumption is that the limitations on the exertion of arbitrary power would have been made more rigorous. ${ }^{161}$

Justice Horace Gray's brief concurring opinion proved to be prophetic: "If Congress is not ready to construct a complete government for the conquered territory, it may establish a temporary government, which is not subject to all the restrictions of the Constitution."162 Justice White's opinion, however, includes an important caveat suggesting that territorial status could not last forever:

Conceding, then, for the purpose of the argument, it to be true that it would be a violation of duty under the Constitution for the legislative department, in the exercise of its discretion, to accept a cession of and permanently hold territory which is not intended to be incorporated, the presumption necessarily must be that that department, which within its lawful sphere is but the expression of the political conscience of the people of the United States, will be faithful to its duty under the Constitution, and, therefore, when the unfitness of particular territory for incorporation is demonstrated, the occupation will terminate. I cannot conceive how it can be held that pledges made to an alien people can be treated as more sacred than is that great pledge given by every member of every department of the government of the United States to support and defend the Constitution. ${ }^{163}$

As discussed earlier, the Boumediene majority also classified the "situational" standard as producing rules of temporary

\footnotetext{
161 Id. at 374-75 (Fuller, C.J., dissenting).

162 Id. at 346 (Gray, J., concurring). This position was eventually adopted by a majority of the Court in Balzac.

163 Id. at 343-44 (White, J. concurring) (emphasis added).
} 
duration. Nevertheless, to this day Puerto Rico continues to be an unincorporated territory of the United States, albeit with an increasingly powerful locally elected government.

Politically, the majority in Downes followed the Republican policy of empire building: territorial expansion unburdened by the concept of having the Constitution follow the flag. In fact, the Court majority was principally composed of republican appointees and the dissents were filed principally by democratappointed justices. The two exceptions in fact prove the policy rule. Former Louisiana Democratic Senator White voted with the Republican majority. His fellow southerner, but Republican appointee, Harlan made a clean break with anti-black racism in his dissent in Plessy v. Ferguson, ${ }^{164}$ and had made his policy choice when he joined the Union Army during the Civil War (White fought for the Confederacy). ${ }^{165}$ So, to the extent that they followed the Republican policies of anti-insular-peoples' nativism and territorial expansion, the alignment of justices was fairly understandable. What is more interesting is how the pro-empire position of a three-justice plurality in a deeply divided Court went on to become the shared constitutional vision that is now unanimous among the justices, no matter their political stripes.

\section{THE DOWNES SUPREMACY: FROM IMPERIAL VACILLATION TO UNANIMOUS PLENARY POWER}

The common phrase "Insular Cases" was immediately used in the media to describe the nine cases of the term of October 1900 when they were filed. The legal literature quickly picked up on this usage as well. ${ }^{166}$ The Supreme Court itself designated them as the "Insular Tariff Cases" as indicated in

164 Plessy v. Ferguson, 163 U.S. 537 (1896). The Court's alignment in the Plessy case is discussed infra notes $243-45$ and accompanying text.

165 See generally JAMES W. ELY, JR., THE FULlER COURT: JUSTICES, RULINGS, AND LEGACY (2003); REBECCA S. SHOEMAKER, THE WHITE COURT: JUSTICES, RuLINGS, AND Legacy (2004); Walter F. PRATT, JR., The SuPreme CoURT UNDER ChIEF Justice EDWARD DOUGLASS WHITE, 1910-1921 (1999).

166 See, e.g., Charles E. Littlefield, The Insular Cases, 15 HARV. L. REv. 169 (1901). 
its Statement of the Case in De Lima v. Bidwell.167 The use of the word insular rather than territory would distinguish the new possessions from the territories existing prior to the Spanish-American War, which were eventually destined for statehood. Accordingly, the United States Supreme Court in Hawaii v. Mankichi uses "Insular Cases" as a reference to the cases resolved in 1901 involving the territorial possessions acquired after the Spanish-American War. ${ }^{168}$ As used in this context, "insular" simply means "relating to, or being an island."169 But another meaning of the term insular might better describe the attitudes: "physically or emotionally removed from others."170

Some authors take a broad view, identifying the Insular Cases as a complex series of decisions that helped create the "American empire." Guadalupe T. Luna, for example, noted that the Scott v. Sanford decision is arguably the first of the Insular Cases because it created the imperial United States with its inherent constructs of citizens and noncitizens within U.S. territorial control; Balzac v. Porto Rico then established the categories of citizenship based on larger or lesser entitlements to constitutional rights. ${ }^{171}$ One might also see them even more generally within the law of conquest or the "right of discovery." In Johnson v. M'Intosh, ${ }^{172}$ the Supreme Court ruled

167 De Lima v. Bidwell, 182 U.S. 1, 2 (1901).

168 Hawaii v. Mankichi, 190 U.S. 197 (1903). As of 2006, the Supreme Court had used the phrase "Insular Cases" in twenty-three of its published opinions, starting with Mankichi, and twenty-eight times has it referred more generally to the cases or to the possessions. (Lexis Search conducted June 26, 2006.) The latest back then was United States v. Lara, 541 U.S. 193 (2004) (regarding tribal authority to prosecute crimes). Rasul v. Bush makes passing reference to "insular possessions" in regards to the habeas corpus statute. Rasul v. Bush, 542 U.S. 466, 475 (2004) (case arising out of detentions in Guantánamo). But Boumediene is the most recent decision that follows the rule of the Insular Cases.

169 WEBSTER'S II NEW COLLEGE DICTIONARY 575 (1999).

170 ENCARTA WORLD ENGLISH DICTIONARY 931 (1999).

171 Guadalupe T. Luna, On the Complexities of Race: The Treaty of Guadalupe Hidalgo and Dred Scott v. Sanford, 53 U. MIAMI L. REV. 691, 708-09 (1999) (noting that Scott $v$. Sanford gave constitutional authority to constructs of citizens and noncitizens within U.S. territorial control). See also Sarah H. Cleveland, Foreign Authority, American Exceptionalism, and the Dred Scott Case, 82 CHI.-KeNT. L. REv. 393 (2007) (a thorough and updated study of the historical context and constitutional bases for the decision).

172 Johnson v. M'Intosh, 21 U.S. 543 (1823). 
that the "right of discovery" and the "right of conquest" gave Europeans legal title over the American continents. It stated as well that Native Americans could not be assimilated, i.e., they could not be "incorporated with the victorious nation, and become subjects or citizens of the government with which they are connected."173 Incorporation was not "practicable," thus requiring the Europeans to choose between "abandoning the country, and relinquishing their pompous claims to it, or of enforcing those claims by the sword." 174

Like American Indians, African slaves were also not allowed to assimilate into American citizenship. Most students of American law know Scott v. Sanford for its shameful definition of African slaves as non-citizens and chattel property rather than as persons entitled to constitutional rights. ${ }^{175}$ But, as President McKinley repeatedly alluded to during the 1900 presidential election campaign, Scott $v$. Sanford was also a Territorial Clause case in which the majority stated:

The power to expand the territory of the United States by the admission of new States is plainly given; and in the construction of this power by all the departments of the Government,

173 Id. at 589.

174 Id. at 590. The Supreme Court justified genocide as follows:

When the conquest is complete ... the conquered inhabitants can be blended with the conquerors, or safely governed as a distinct people. . . .

But the tribes of Indians inhabiting this country were fierce savages, whose occupation was war, and whose subsistence was drawn chiefly from the forest. To leave them in possession of their country, was to leave the country a wilderness; to govern them as a distinct people, was impossible, because they were as brave and as high spirited as they were fierce, and were ready to repel by arms every attempt on their independence.

Id. at 589-90.

175 Scott v. Sanford, 60 U.S. 393, 404-05 (1856) (African slaves imported into the United States and their descendants, free or otherwise, "are not included, and were not intended to be included, under the word 'citizens' in the Constitution, and can therefore claim none of the rights and privileges which that instrument provides for and secures to citizens of the United States. On the contrary, they were at that time considered as a subordinate and inferior class of beings, who had been subjugated by the dominant race, and whether emancipated or not, yet remained subject to their authority, and had no rights or privileges but such as those who held the power and the Government might choose to grant them.") 
it has been held to authorize the acquisition of territory, not fit for admission at the time, but to be admitted as soon as its population and situation would entitle it to admission. It is acquired to become a State, and not to be held as a colony and governed by Congress with absolute authority.... ${ }^{176}$

Scott v. Sanford ruled that Congress could not ignore the three constitutional provisions that protected slavery when legislating for new territories. ${ }^{177}$ Paradoxically, while the Civil War and the Thirteenth and Fourteenth Amendments reversed the de jure exclusion of African slaves from citizenship, the Downes decision creates a new kind of lesser citizenship: it reversed Scott v. Sanfords interpretation of the Territorial Clause, allowing Congress to ignore constitutional provisions prohibiting discriminatory taxation and requiring trial by jury.

Clearly Downes and its companion cases fit well in the larger context of the jurisprudence of American expansionism. Johnson v. M'Intosh and Scott v. Sanford represent the first age of American territorial expansion characterized by territorial conquest from the native inhabitants, followed by colonization by the growing U.S. immigrant population. The second age of expansion did not involve this territorial incorporation into the nation or the re-population of the territory by "American" "pilgrims" rather than by the unassimilable Latinas/os. 178 This article is concerned with this second age of expansionism that started with the Spanish-American War and was legally defined by the Insular Cases that followed it.

176 Id. at 447 (emphasis added).

177 U.S. CoNST. art. I, $\S 2$, cl. 3 (slaves contribute $3 / 5$ to their masters' entitlement to congressional representation); U.S. CoNST. art. I, $\S 9$, cl. 1 (limiting the power of Congress to restrict the slave trade), U.S. CONST. art. IV, $\$ 2$, cl. 3 (runaway slaves had to be returned to slave states). See generally RACE AND RACES, supra note 5, at 103-04 (explaining that "[d]espite the protections of slavery in the Constitution, its drafters were careful not to use the word 'slave' at all, despite language that was understood by all to refer to slaves.").

178 On Latina/o assimilation generally, see Kevin R. Johnson, "Melting Pot" or "Ring of Fire"?: Assimilation and the Mexican-American Experience, 85 CAL. L. REV. 1259 (1997) (a poignant discussion of growing up Latina/o in California). See also George A. Martinez, Latinos, Assimilation and the Law: A Philosophical Perspective, 20 ChICANO-LATINO L. REV. 1 (1999) (drawing analogies between American demands of assimilation and insect biology and Star Trek's Borg characters). 
The first reported case in which the facts occurred in or around Puerto Rico after the start of the Spanish-American War is The Olinde Rodrigues, which involved the seizure of a vessel by the United States Navy during its blockade of San Juan harbor in July of 1898 . The matter was decided on May $15,1899.179$ But the constitutional law of the second age of expansion starts with the nine Insular Cases resolved in 1901. While no knowledgeable person would challenge Downes's labeling as one of the Insular Cases, no definitive listing of those decisions is agreed upon. ${ }^{180}$ This article divides them into three categories:

First, the nine cases of the October Term of 1900 , with seven opinions issued on May 27, 1901, and two in December of 1901 , in which a deeply divided Supreme Court, under Chief Justice Melville Weston Fuller, narrowly allowed the McKinley administration and Congress to exercise plenary powers in dealing with the territorial acquisitions resulting from the Spanish-American War. ${ }^{181}$ Justice White's concurring opinion in Downes adopts the categories of incorporated and unincorporated territories as determinative of the bundle of constitutional rights and obligations that apply in the territories. Hereafter, these cases will be referred to as "Downes and its companion cases."

Second, the "intermediate cases" resolved between 1903 and 1922, in which the Fuller Court, on its way to becoming the White Court in 1910, and the Taft Court in 1921, tried to agree

179 The Olinde Rodrigues, 174 U.S. 510 (1899) (about ownership of vessel taken by the U.S. navy during its blockade of San Juan harbor).

180 For a general discussion of this debate, see Efrén Rivera Ramos, The Legal Con. struction of American Colonialism: The Insular Cases (1901-1922), 65 REV. JUR. U.P.R. 225 (1996); EFren RIVERA RAMOS and THE LEgAL CONSTRUCTION OF IDENTTTY: THE JUDICIAL AND SOCIAL LEgACY OF AMERICAN COLONIALISM IN PUERTO RICO (2001). See also $A$ Convenient Constitution, supra note 5 , at $975 \mathrm{n.4}$ and accompanying text. The most serious work on the Insular Cases was done by José Trías Monge, the late Chief Justice of the Puerto Rico Supreme Court, in the first volume of this five volume collection on the constitutional history of Puerto Rico. See 1 Historia Constitucional, supra note 54.

181 I purposely avoid stating that the Court was led by Chief Justice Fuller, as on this matter he was mostly among the dissenters or at best concurred in the judgments. See generally ELY, supra note 165. 
on a single constitutional doctrine in its application of the Territorial Clause of the Constitution.

Third, a single decision that is arguably the last of the Insular Cases: Balzac v. Porto Rico. A unanimous Supreme Court settled upon Justice White's plurality opinion and his incorporated/unincorporated territory dichotomy as the applicable constitutional doctrine, and this remains the rule to this day, as recognized by all nine justices in Boumediene. Subsequent cases have merely reinforced the continued status of Downes and Balzac as the law of the land in the application of the Territorial Clause of the Constitution of the United States.

The cases between Downes and Balzac, those in the second category of Insular Cases, start with Hawaii v. Mankichi, in 1903, in which the Court ruled that Hawaiian territorial law, not the Seventh Amendment, governed the defendant's right to a criminal jury trial. White and McKenna concurred, stating that congress had not expressly incorporated Hawaii, therefore full constitutional protections such as the right to jury trial did not apply in the territory. ${ }^{182}$ The decision was significant because Justice Oliver Wendell Holmes had replaced Justice Horace Gray on the Supreme Court and Justice Shiras was replaced by Justice William Day. ${ }^{183}$ Mankichi was soon followed by González v. Williams, a unanimous ruling subscribed by Chief Justice Fuller in favor of a Puerto Rican woman seeking entry into New York City after the Immigration Commissioner had ruled her a foreigner and excluded her from the city. The Court ruled that Puerto Ricans while not citizens of the United States are nonetheless subjects or "nationals" of this country and therefore not foreigners for purposes of the immigration laws. ${ }^{184}$

\footnotetext{
182 Hawaii v. Mankichi, 190 U.S. 197, 218-19 (1903).

183 Id. Fuller, Harlan, Brewer, and Peckham dissented. Id. at 221-26. Harlan filed a separate dissent. Id. at 226-49.

184 Gonzales v. Williams, 192 U.S. 1 (1904). Citing Elk v. Wilkins, 112 U.S. 94 (1884), the Gonzales Court ruled that Puerto Ricans were "Nationals" of the United States, and were neither citizens, for purposes of constitutional guarantees, nor foreigners, for purposes of the immigration laws.
} 
In 1904, the Court issued Kepner v. United States, ${ }^{185}$ Binns v. United States, ${ }^{186}$ and, more importantly, Dorr v. United States. ${ }^{187}$ In Dorr, a case originating in the Philippines, White, now joined by a majority of the Court, reaffirmed the incorporation doctrine that he first articulated in Downes and found that the Philippines were an unincorporated territory. ${ }^{188}$

In 1906, a case involving territorial Alaska, Rassmussen $v$. United States, reiterated the result of the 1901 decisions and continued to solidify a prevailing view from among the many articulated by the justices in the prior opinions. Writing for the majority, Justice White ruled that Alaska, unlike Puerto Rico, was an incorporated territory of the United States, with full constitutional protections for its residents. Harlan concurred in the result, continuing to reject the incorporated/unincorporated distinction and stating that constitutional guarantees apply fully in all territories. Brown also concurred, expressing his view that congress has exercised plenary powers in granting such rights to Alaskans. ${ }^{189}$ Other cases continuing to apply White's incorporation doctrine in this period were Dowdell v. United States in $1911^{190}$ and Porto Rico v. Rosaly in 1913, in which then Chief Justice White wrote for a unanimous Court that Puerto Rico was "a completely organized Territory, although not a territory incorporated into the United States."191

185 Kepner v. United States, 195 U.S. 100 (1904).

186 Binns v. United States, 194 U.S. 486 (1904) (involving taxation in Alaska; opinion by Brewer, with indication that Harlan took no part in the case, but no mention of the other justices either joining or dissenting, though Brewer speaks for the Court).

187 Dorr v. United States, 195 U.S. 138 (1904).

188 Id. at 142.43 (only Harlan remained firm in opposing the imperial constitution; Fuller and other former dissenters concurred in the result, though they still noted their rejection of the incorporation notion).

189 Rassmussen v. United States, 197 U.S. 516 (1905). Justice Moody had replaced Justice Henry Billings Brown on the Court by then.

190 Dowdell v. United States, 221 U.S. 325, (1911) (dissent by Harlan, without opinion; Day writes for all others that Dorr disposes of the matter and that Philippine Supreme Court properly affirmed defendants' convictions after requiring trial court to supplement record on appeal.)

191 Porto Rico v. Rosaly, 227 U.S. 270, 274 (1913) (quoting Kopel v. Bingham, 211 U.S. 468, 476 (1909) (ruling that Puerto Rico's government enjoyed sovereign immunity). White became Chief Justice by appointment of President William Howard Taft, in 1910. See SHOEMAKER, supra note 165; PRATT, supra note 165. 
The Foraker Act-the organic act for Puerto Rico interpreted in Downes - was replaced by the Jones Act of 1917, making changes to the local government and, most significantly, giving Puerto Ricans U.S. citizenship. ${ }^{192}$ In 1922, Balzac v. Porto Rico applied the Jones Act and in the process turned Justice White's concurrence in Downes v. Bidwell into normative constitutional doctrine, and still quite applicable precedent, as noted in Boumediene. The Court unanimously affirmed Down$e s$, and cited Justice White's opinion and the incorporation doctrine as controlling. ${ }^{193}$ Balzac v. Porto Rico was resolved by the U.S. Supreme Court after passage of the Jones Act. By adopting one of the many views articulated in the earlier Insular Cases, this case helped clarify the constitutional relationship between Puerto Rico and the United States. It stated that "the opinion of Mr. Justice White of the majority, in Downes v. Bidwell, has become the settled law of the Court."194 On the specific facts of the case, Balzac ruled that even after the grant of U.S. citizenship to the residents of Puerto Rico, not all U.S. constitutional protections applied to the territory. ${ }^{195}$ Fundamental rights, generally those guaranteed by the Due Process Clause, would automatically apply to U.S. citizens living in the unincorporated territories, but personal freedoms would not. Among the latter are the right to a trial by jury and the right to uniform taxation. ${ }^{196}$

192 See Jones Act of 1917, in 1 P.R. LAWS ANN., at 72-73 (2008) (conferring U.S. citizenship on all "citizens of Puerto Rico;" it adopted the definition of Puerto Rican citizenship included in section 7 of the Foraker Act). This new law, however, left some confusion about Puerto Rican citizenship that required judicial resolution. See 1 P.R. LAWS ANN., at 83, 120. For an interesting discussion of some of the perils of "statutory citizenship" for those born in U.S. territories, see Gabriel J. Chin, Why Senator John McCain Cannot Be President: Eleven Months And a Hundred Yards Short Of Citizenship, 107 MiCH. L. REv. 1, 1-2 (2008) (arguing that the then Presidential Candidate was not a "natural born" citizen under Art. II § 1 of the Constitution due to an exclusion in the statute applicable in the Panama Canal Zone at the time of his birth). See also ROMÁN, supra note 5; Jimenez v. Glover, 255 F.2d 54 (1st Cir. 1958).

193 Balzac v. Porto Rico, 258 U.S. 298 (1922).

194 Id. at 305.

195 The Court cites with approval Justice White's position. Id. (quoting Dorr v. United States, 195 U.S. 138, 149 (1904)).

196 The Court explained the applicability of fundamental rights to the unincorporated territories. Balzac, 258 U.S. at 312-13. Balzac itself rules that trial by jury was 
In Reid v. Covert, in 1957, the Supreme Court came close to overruling Downes and Balzac, but could muster only a plurality. The case involved two civilian wives-both U.S. citizens-who killed their husbands who were members of the U.S. armed forces, on U.S. military bases in England and Japan, respectively, and were tried by military tribunals. The $\mathrm{Su}$ preme Court held that depriving the women of a right to a jury trial in a civilian court violated their constitutional rights. The Court ruled that the Constitution protects U.S. citizens even outside U.S. territory. ${ }^{197}$ Specifically criticizing Balzac and Downes, Justice Hugo Black, joined by Chief Justice Earl Warren and Associate Justices William Douglas and William Brennan, wrote:

This Court and other federal courts have held or asserted that various constitutional limitations apply to the Government when it acts outside the continental United States. While it has been suggested that only those constitutional rights which are "fundamental" protect Americans abroad, we can find no warrant, in logic or otherwise, for picking and choosing among the remarkable collection of "Thou shalt nots" which were explicitly fastened on all departments and agencies of the Federal Government by the Constitution and its Amendments. Moreover, in view of our heritage and the history of the adoption of the Constitution and the Bill of Rights, it seems peculiarly anomalous to say that trial before a civilian judge and by an independent jury picked from the common citizenry is not a fundamental right. ${ }^{198}$

But concurring in the result only, Justices Felix Frankfurter and John Marshall Harlan II (the grandson of the John Marshall Harlan involved in Downes) ${ }^{199}$ distinguished the Insular Cases and believed them to be good law. ${ }^{200}$ In his opinion Frankfurter put it this way:

one such right. See also De Lima v. Bidwell, 182 U.S. 1 (1901); Downes v. Bidwell, 182 U.S. 244 (1901) (both cases concerning taxation).

197 Reid v. Covert, 354 U.S. 1, 8 (1957).

198 Id. at 8-9 (footnotes omitted).

199 DAVID SchULTZ, ENCYCLOPEDIA OF THE SUPREME COURT, 196-97 (2005).

200 Reid, 354 U.S. at 41 (Frankfurter, J., concurring); Id. at 65 (Harlan, J., concurring). 
The results in the cases that arose by reason of the acquisition of exotic "Territory" do not control the present cases, for the territorial cases rest specifically on Art. IV, $\S 3$, which is a grant of power to Congress to deal with "Territory" and other Government property. Of course the power sought to be exercised in Great Britain and Japan does not relate to "Territory."201

That Puerto Rico is still one of the "exotic territories" was directly confirmed in Califano v. Torres, ${ }^{202}$ where the Supreme Court reiterated what it had said in the Insular Cases, that Puerto Rico was an unincorporated territory of the United States. The three appellees in this case had moved from Massachusetts, Connecticut, and New Jersey to Puerto Rico. While living in the states, they had received Supplemental Security Income through a federal Social Security Administration program for "qualified aged, blind, and disabled persons." When they arrived in Puerto Rico, however, their benefits were canceled. The Supreme Court, in a per curiam opinion, let this discrimination stand, explaining that:

The exclusion of Puerto Rico in the amended program is apparent in the definitional section. ... [T] he Act . . . states that no individual is eligible for benefits during any month in which he or she is outside the United States. The Act defines "the United States" as "the 50 States and the District of Columbia."203

The justices then concluded that:

[W] deal here with a constitutional attack upon a law providing for governmental payments of monetary benefits. Such a statute "is entitled to a strong presumption of constitutionality." "So long as its judgments are rational, and not invidious, the legislature's efforts to tackle the problems of the poor and the needy are not subject to a constitutional straitjacket." 204

201 Id. at 53 (Frankfurter, J. concurring).

202 Califano v. Torres, 435 U.S. 1, 1-3 (1978).

203 Id. at 2-3 (citations omitted).

204 Id. at 5 (citations omitted). How curious that the Court uses the language of the war on poverty to justify the denial of funds to the poorest American citizens. See AMERICA'S COLONY, supra note 1, at 155-58. 
The "rational basis" for Congress's action in this case was described by the Court in Harris v. Rosario. "In [Califano], we concluded that a similar statutory classification was rationally grounded on three factors: Puerto Rican residents do not contribute to the federal treasury; the cost of treating Puerto Rico as a State under the statute would be high; and greater benefits could disrupt the Puerto Rican economy."205 In Torres v. Puerto Rico, the U.S. Supreme Court ruled that Congress had the power to grant, and conversely to withhold, constitutional guarantees from the U.S. citizens who may be found in Puerto Rico. ${ }^{206}$

Harris v. Rosario ${ }^{207}$ exposes Puerto Rico's continued territorial status. In this case the U.S. Supreme Court, summarily, but with a written opinion, ruled that the lower level of reimbursement provided to Puerto Rico under the Aid to Families with Dependent Children program did not violate the Fifth Amendment's Equal Protection Clause. In accordance with its authority under the Territorial Clause of the U.S. Constitution, Congress can make any necessary rules that affect the territories, and it may treat Puerto Rico differently from states if it has a rational basis for its actions. Justice Thurgood Marshall noted in his lonely dissent that he and three of his contemporaries on the Court had expressed opposition to Downes and its denial of constitutional protections to U.S. citizens, but they did not join him here, and Harris ultimately really illustrates how the Insular Cases have become entrenched constitutional doctrine. ${ }^{208}$

205 See Harris v. Rosario, 446 U.S. 651, 652 (1980). First, while Puerto Ricans do not pay federal income taxes, they do pay Social Security and other federal taxes, and second, it is difficult to conceive how $\$ 300$ million for children's welfare would negatively disrupt the Puerto Rican economy. See also AMERICA's COLONY, supra note 1, at 15558 (discussing Puerto Rico's economy).

206 See Torres v. Puerto Rico, 442 U.S. 465 (1979). But at least four Justices expressed the view that more constitutional guarantees ought to apply. Id. at 475-76 (Brennan, J., concurring in the judgment with Stewart, Marshall, and Blackmun). Boumediene refers to Torres expressly as discussed supra in Part I.

207 Harris, 446 U.S. at 651.

208 Id. at 653-54. (Marshall, J., dissenting). Marshall wrote:

It is important to remember at the outset that Puerto Ricans are United States citizens and that different treatment to Puerto Rico under AFDC may 
Prior to Boumediene, the most recent reference to the Insular Cases could be found in Justice Thomas's opinion concurring in the judgment in United States v. Lara, in which, citing Reid v. Covert, he writes: "The 'Insular Cases,' which include the Hawaii and Puerto Rico examples . . . involved Territories of the United States, over which Congress has plenary power to govern and regulate."209

As long as the Insular Cases remain good law-and Boumediene clearly rules that they do-Congress, in the exercise of its authority under the Territorial Clause, may unilaterally change the statutory relationship between the territories and the United States, as it deems appropriate. Moreover, one Congress cannot bind another; therefore, statutory language purporting to limit future legislative enactments is unconstitutional. ${ }^{210}$ Nevertheless, to this day, the Puerto Ricans continue to travel with a U.S. passport but without the legal right to a separate Puerto Rican citizenship.

Attempts to create a legal Puerto Rican citizenship have been legally and politically rebuffed. For example, in an interesting but sui generis case, the Supreme Court of Puerto Rico held that Puerto Rican citizenship was independent of U.S. citizenship because of certain provisions of Puerto Rican law. The opinion in Ramírez de Ferrer v. Mari Brás, was issued on

well affect the benefits paid to these citizens. While some early opinions of this Court suggested that various protections of the Constitution do not apply to Puerto Rico, the present validity of those decisions is questionable. We have already held that Puerto Rico is subject to the Due Process Clause of either the Fifth or Fourteenth Amendment and the equal protection guarantee of either the Fifth or the Fourteenth Amendment. The Fourth Amendment is also fully applicable to Puerto Rico, either directly or by operation of the Fourteenth Amendment. At least four Members of this Court are of the view that all provisions of the Bill of Rights apply to Puerto Rico.

Id. (internal citations and footnote omitted).

209 United States v. Lara, 541 U.S. 193, 225 (2004) (citing U.S. CoNST. art. IV, § 3, cl. 2; Reid v. Covert, 354 U.S. 1, 13, (1957)).

210 See I.N.S. v. Chadha, 462 U.S. 919 (1983) ("legislative veto," the reservation of authority by the Congress to invalidate executive action taken pursuant to passed statute unconstitutional); see also Bowsher v. Synar, 478 U.S. 714, 733-34 (1986) (Gramm-Rudman Balanced Budget Act provisions requiring specific executive action to reduce deficit violated constitutional separation of powers). 
November 18, 1997, according to the published text..11 On the day before the opinion was issued, the Puerto Rican law alluded to in the opinion was amended to require both U.S. citizenship and Puerto Rico residency in order to become a citizen of the island. ${ }^{212}$ This made the matter of law addressed in the opinion moot. The U.S. Department of State later rescinded Juan Mari-Brás's renunciation of his U.S. citizenship, returning him to his legal status before the case was resolved. Therefore, Puerto Ricans are limited to the legal citizenship of the United States, but they are not entitled to the full enjoyment of the rights usually associated with that citizenship.

\section{DOWNES'S LEGACY: CITIZENSHIP OF A SECOND-ClaSS}

The most enduring effect of Downes v. Bidwell and the Insular Cases is the effective definition of a lesser level of citizenship for territorial subjects of the United States. ${ }^{213}$ Section 1 of the Fourteenth Amendment reads, in part: "All persons born or naturalized in the United States and subject to the jurisdiction thereof, are citizens of the United States and of the State wherein they reside." 214 To the extent that this provision creates formal universal U.S. citizenship, it is belied by the reality of that citizenship, which is often constructed on the basis of faultlines defined by essentialized notions of race. The terri-

211 Ramírez de Ferrer v. Mari Brás, 144 P.R. Dec. 141 (1997). Plaintiff Miriam Ramírez de Ferrer is a pro-statehood activist who later serves as a Puerto Rican senator. Juan Mari Brás is the founder of the MPI and the Socialist Party of Puerto Rico.

212 P.R. LAWS. ANN. tit. 1, $\$ 7$ (2008). See also Pedro Malavet.Vega, Derechos y LIBERTADES CONSTITUCIONALES EN PUERTO RICO 589 \& n.1454 (2003) (the note discusses the controversy that arose as a result of the rather curious timing of the amendment to the statute).

213 Therefore, until they were granted U.S. citizenship in 1917, Puerto Ricans were, in the words of a Democratic U.S. senator, "without a country. Can any man conceive of a more tyrannical form of government?" CARR, supra note 82, at 36 (citation omitted). Under international law, Puerto Rican citizenship is not recognized. Id.

214 U.S. CoNST. amend. XIV, § 1 . The section continues as follows:

No State shall make or enforce any law which shall abridge the privileges or immunities of citizens of the United States; nor shall any State deprive any person of life, liberty, or property, without due process of law; nor deny to any person within its jurisdiction the equal protection of the laws.

Id. 
torial peoples are just one example of this. One can easily include American Indians, African Americans, ${ }^{215}$ Asian Americans, ${ }^{216}$ and Mexican Americans among the victims of these citizenship constructs. ${ }^{217}$

As noted by Professor Sarah H. Cleveland, the treatment of territorial citizens fits within a disturbing pattern of constitutional rules that are designed to have discriminatory effects on "discrete and insular minorities" 218 within the United States: territorial citizens, American Indians, and immigrants in our territory. ${ }^{219}$ "The Indian, alien, and territory cases often have been ignored by mainstream constitutional law scholars as late-nineteenth-century anomalies of American constitutional jurisprudence. The doctrines developed during this period, however, continue to be the controlling constitutional authority in all three areas."220

For example, the "plenary power" doctrine-giving almost absolute deference to Congress to legislate the treatment of immigrants-initially developed in the nineteenth century

215 See discussion supra notes 172-77 and accompanying text (discussing Johnson $v$. M'Intosh and Scott v. Sanford).

216 To this limited study, we might add the mistreatment of Native Americans and Native Hawaiians. See Eric K. Yamamoto, Carrie Ann Y. Shirota, \& Jayna Kanani Kim, Indigenous Peoples' Human Rights in U.S. Courts, in MORAL IMPERIALISM: A CRITICAL ANTHOLOGY 300-19 (2002).

217 As detailed by Guadalupe Luna, Mexicans were dispossessed of their land despite their formal U.S. citizenship and their legal rights. Guadalupe T. Luna, Chicana/Chicano Land Tenure in the Agrarian Domain: On the Edge of a "Naked Knife," 4 MICH. J. RACE \& L. 39 (1998). See also RACE AND RACES, supra note 5, at 262.

218 United States v. Carolene Prods. Co., 304 U.S. 144, 153 n.4 (1938) ("[P]rejudice against discrete and insular minorities may be a special condition, which tends seriously to curtail the operation of those political processes ordinarily to be relied upon to protect minorities, and which may call for a correspondingly more searching judicial inquiry.") (citations omitted).

219 See Sarah H. Cleveland, Powers Inherent in Sovereignty: Indians, Aliens, Territories, and the Nineteenth Century Origins of Plenary Power over Foreign Affairs, 81 TEX. L. REV. 1 (2002).

220 Id. at 12. Professor Cleveland identifies two other scholars who have also discussed this pattern: T. ALEXANDER ALEINIKOFF, SEMBLANCES OF SOVEREIGNTY: THE CONSTTTUTION, THE STATE, AND AMERICAN CITIZENSHIP (2002), and Natsu Taylor Saito, Asserting Plenary Power Over the "Other": Indians, Immigrants, Colonial Subjects, and Why U.S. Jurisprudence Needs to Incorporate International Law, 20 YALE L. \& POL'Y REV. 427 (2002). Cleveland, supra note 219, at 13 n.50 and accompanying text. 
shortly before the Spanish-American War, ${ }^{221}$ remains in effect. ${ }^{222}$ As Dean Kevin R. Johnson concludes: "The Supreme Court has consistently refused to disturb discriminatory immigration laws. As Justice Frankfurter put it, 'whether immigration laws have been crude and cruel, whether they have reflected xenophobia in general or anti-Semitism or antiCatholicism, the responsibility belongs to Congress."223 Whether the Puerto Ricans were, to the United States, citizens, alien immigrants, or something else, was unclear after the SpanishAmerican War. It was initially left to the Supreme Court rather than to Congress to define it.

\section{Article IX of the Treaty of Paris provided that:}

Spanish subjects, natives of the Peninsula, residing in the territory over which Spain by the present treaty relinquishes or cedes her sovereignty, may remain in such territory or may remove therefrom, retaining in either event all their rights of property, including the right to sell or dispose of such property or of its proceeds; and they shall also have the right to carry on their industry, commerce and professions, being subject in respect thereof to such laws as are applicable to other foreigners....

The civil rights and political status of the native inhabitants of the territories hereby ceded to the United States shall be determined by the Congress. ${ }^{224}$

Although the peninsulares (natives of the Iberian Peninsula) were given the choice of retaining their Spanish citizenship, the native-born Puerto Ricans were not; they lost the Spanish citizenship that had been granted in late 1897. Yet again, the

221 See Ping v. United States, 130 U.S. 581, 606 (1889) (also known as The Chinese Exclusion Case, if Congress "considers the presence of foreigners of a different race in this country, who will not assimilate with us, to be dangerous to its peace and security . . . [that] determination is conclusive upon the judiciary.").

222 See Demore v. Kim, 538 U.S. 510, 521 (2003) (citation omitted) (reasserting Congress' "broad power over naturalization and immigration").

${ }^{223}$ Kevin R. Johnson, Minorities, Immigrant and Otherwise, 118 YALE L.J. POCKET PART 77 (2008), http://thepocketpart.org/2008/10/28/johnson.html (citing Harisiades v. Shaughnessy, 342 U.S. 580, 597 (1952) (Frankfurter, J., concurring)).

224 Treaty of Paris, 1898, in 1 P.R. LAWS ANN., at 20 (2008) (emphasis added). 
island's native inhabitants became subjects, but not citizens, of a colonial power. Despite the language of the Treaty, until Congress acted on the matter, the legal citizenship of Puerto Rico's non-Spanish inhabitants would be defined by the U.S. courts, initially and enduringly, in Downes v. Bidwell.

Downes effectively defined the legal rights of the inhabitants of the territories of the United States, and the power of the federal executive and legislative branches to regulate the land and its people. The case concerned the power of the federal government towards persons under our control who are, sometimes irrespective of citizenship status, racialized as something "other" than "Americans." Racism, supported by social Darwinism as pseudo-science, generally justified the take over of the lands belonging to "inferior races." 225 However, what "racial superiority" entailed had to be recast during the period of the Insular Cases.

Westward "manifest destiny" defined Anglo-white racial supremacy as making that group capable of "outbreeding" the "inferior" races. Reginald Horsman explains:

By the 1850s the American sense of idealistic mission had been corrupted, and most of the world's peoples were condemned to permanent inferiority or even to extinction. General world progress was to be accomplished only by the dominating power of a superior race, and a variety of lesser races were accused of retarding rather than furthering world progress. A traditional colonial empire had been rejected [in the continental United States], but it was believed that the expansion of a federal system might ultimately prove possible as American Anglo-Saxons outbred, overwhelmed, and replaced "inferior" races. This time was to be hastened by commercial penetration of the most distant regions of the earth . . ..226

Once the United States reached the island territories, however, biological reality required white racial supremacy to redefine itself no longer to mean that the "superior" race could

225 See generally Reginald HoRSMan, RACE AND MANIFEST DESTINY: THE ORIGINS OF AMERICAN RACIAL ANGLO-SAXONISM (1981).

226 Id. at 297. 
"outbreed" the "inferior" one. Rather, now it was the "inferior" race that bred like rats or cockroaches, or, at least, enough that it could not be displaced by white anglo immigration. While explaining the rule of the Insular Cases, as discussed later in this section, the Supreme Court acknowledged that Puerto Rico and other territories occupied as a result of the SpanishAmerican War could not be colonized by an Anglo-Saxon majority. ${ }^{227}$ New Dealer Rexford G. Tugwell-the last non-Puerto Rican appointed Governor of the island-illustrates the United States' racialization of Puerto Ricans, and its views of fertility. When Tugwell was the secretary of agriculture, he accompanied First Lady Eleanor Roosevelt on her trip to Puerto Rico in March 1934, about which he wrote:

I rather dislike to think that our falling fertility must be supplemented by these people. But that will probably happen. Our control of the tropics seems to me certain to increase immigration from here and the next wave of the lowly ... succeeding the Irish, Italians, and Slavs . . . will be these mulatto, Indian, Spanish people from the south of us. They make poor material for social organization but you are going to have to reckon with them. ${ }^{228}$

The Spanish-American War thus left the United States in charge of new subjects who were clearly cast as "racially inferior." At the same time, the war acted as uniter of white southerners and northerners against a common enemy. In particular, the war served as a military reconciliation between white officers of the former confederate armed forces and the professional military establishment. In his inaugural address at the start of his second term on March 4, 1901, President McKinley noted this phenomenon when he stated that as a result of the Spanish-American War, "We are reunited. Sectionalism has disappeared. Division on public questions can no longer be

227 See discussion infra notes 232-34 and accompanying text (concerning Balzac).

228 ARTURo MORAles CARRIón, PUERTO Rico: A POLITICAL AND CUltural History 232 (1983). 
traced by the war maps of $1861 . " 229$ On Memorial Day on May 30, 1905, Senator Foraker, for whom Puerto Rico's organic act of 1900 was named, delivered an address as part of his work to have the graves of confederate soldiers in northern cemeteries "treated with due respect," which illustrates this concept more explicitly. He said:

The Spanish-American war was attended with many good results, but one of the best was the impetus it gave to the restoration of cordial relations and the spirit of union and Americanism throughout the country. It gave the young men of the South an opportunity to put on the blue and show their loyalty and devotion to the flag, and to win, as they did, a heroic share of the glory and greatness that were added to the Republic; while their representatives in public life distinguished themselves by the conspicuous and patriotic character of their utterances and services. What has followed is but the natural result, and every survivor of the Union Army should be profoundly thankful that his life has been spared to see such a complete vindication of all that for which he contended. ${ }^{230}$

The racial paradigm that would prevail after North-South white reconciliation would be that of Southern white supremacy. Rubin Francis Weston explains:

Those who advocated overseas expansion faced this dilemma: What kind of relationship would the new peoples have to the body politic? Was it to be the relationship of the Reconstruction period, an attempt at political equality for dissimilar races, or was it to be the Southern "counterrevolutionary" point of view which denied the basic American constitutional rights to people of color? The actions of the federal government during the imperial period and the relegation of the $\mathrm{Ne}$ gro to a status of second-class citizenship indicated that the Southern point of view would prevail. The racism which caused the relegation of the Negro to a status of inferiority

229 William McKinley, Second Inaugural Address of William McKinley: Monday, March 4, 1901, The Avalon Project: Documents IN LAW, History aND Diplomacy, http://avalon.law.yale.edu/19th_century/mckin2.asp (last visited Mar. 15, 2010).

230 Address of Senator Foraker at Arlington, Memorial Day, May 30, 1905, ARLINGTON NATIONAL CEMETERY WEBSITE, http://www.arlingtoncemetery.net/foraker1905.htm (last visited Mar. 15, 2010). 
was to be applied to the overseas possessions of the United States. ${ }^{231}$

In adopting the incorporated/unincorporated territories categories created by Justice White, Balzac constitutionally constructs the U.S. citizenship of Puerto Ricans as second class as long as they remain on the territory of Puerto Rico. It distinguishes between the rights of U.S. citizens living in Puerto Rico and U.S. citizens living in "the United States proper." The Court expressly indicates that as long as they choose to remain on the island, Puerto Ricans who are U.S. citizens will not enjoy the full rights of American citizenship. It thus also distinguishes between Puerto Ricans as individual U.S. citizens and as collective inhabitants of Puerto Rico. As individuals, they are free "to enjoy all political and other rights" granted to U.S. citizens if they "move into the United States proper." But as long as they remain on the island, they cannot fully enjoy the rights of U.S. citizenship. ${ }^{232}$ The Supreme Court explained the motivation behind this construction of Puerto Rican secondclass citizenship in nativistic terms when it distinguished the island from Alaska:

Alaska was a very different case from that of Porto Rico. It was an enormous territory, very sparsely settled, and offering opportunity for immigration and settlement by American citizens. It was on the American continent and within easy reach of the then United States. It involved none of the difficulties which incorporation of the Philippines and Porto Rico presents .... ${ }^{233}$

This statement, which is the Court's interpretation of the Act giving U.S. citizenship to Puerto Ricans, clearly assumes that Puerto Rican U.S. citizens are not the "American citizens"

231 RUBIN FranCIS WESTON, RACISM IN U.S. IMPERIALISM: THE INFLUENCE OF RACIAL ASSUMPTIONS ON AMERICAN FOREIGN POLICY, 1893-1946, at 15 (1972) (footnote omitted). Cornel West described the normative paradigm of "American" liberalism that produced these injustices. See Cornel West, The Role of Law in Progressive Politics, in The Politics of LaW: A Progressive Critique 708, 709 (David Kairys ed., 3d ed. 1998).

${ }^{232}$ Balzac v. Porto Rico, 258 U.S. 298, 311 (1922).

233 Id. at 309 (emphasis added). 
who could resettle an "American" state. While recognizing the impossibility of creating an Anglo-Saxon majority on the island, the Court also constructed Puerto Ricans as "others." Because Puerto Ricans are so "other," the incorporation of the territory that they populated into the United States could not be inferred; it had to be clearly expressed by Congress. ${ }^{234}$ The rule of the Insular Cases, which the Court consistently mischaracterizes as "situational" and "transitional" vis-à-vis any one territory, has allowed Congress to maintain our island empire by constitutional default for over a century.

\section{CONCLUSION: A DOWNES RULE FOR CITIZENS THAT THE BOUMEDIENE COURT REFUSES TO SEE}

As the Boumediene opinion pushes two years of age, its historical and precedential foundation in the Insular Cases is not substantially and seriously discussed, and is even less understood, in legal discourse in the United States. More generally, the Insular Cases are but legal footnotes in U.S. legal scholarship, outside of Critical Race Theory generally ${ }^{235}$ and Lat-

234 Again, the Supreme Court is rather clear in Balzac.

The jury system needs citizens trained to the exercise of the responsibilities of jurors. . . . Congress has thought that a people like the Filipinos, or the Porto Ricans, trained to a complete judicial system which knows no juries, living in compact and ancient communities, with definitely formed customs and political conceptions, should be permitted themselves to determine how far they wish to adopt this institution of Anglo-Saxon origin, and when.

Id. at 310.

235 All the works are simply too numerous to be referenced here, but I cite many of them in the notes to this article. More generally, Cornell West writes that:

Critical Race Theory is the most exciting development in contemporary legal studies. This comprehensive movement in thought and life-created primarily, though not exclusively, by progressive intellectuals of colorcompels us to confront critically the most explosive issue in American civilization: the historical centrality and complicity of law in upholding white supremacy (and concomitant hierarchies of gender, class, and sexual orienta. tion).

Cornel West, Foreword to Critical Race TheORY: The Key Writings That Formed THE MOVEMENT (Kimberlé Crenshaw et al. eds., 1995). 
Crit Theory in particular. ${ }^{236}$ Professor Christina Duffy Burnett does identify some significant, although, as she notes, not broad-based progress in their incorporation into the traditional law school curriculum, particularly the work of constitutional law scholar Sanford Levinson and his inclusion of a section dedicated to the Insular Cases in his Constitutional Law casebook. ${ }^{237}$ But Professor Levinson's call for Installing the Insular Cases into the Canon of Constitutional Law unfortunately appears to have been heeded only by himself in the world of Constitutional law casebook and treatise authors, ${ }^{238}$ once again, outside CRT. 239

In spite of the substantial work of Critical Race Scholars and of Professor Levinson's casebook, more law students today will study Justice Edward Douglass White's interpretation of the Sherman Antitrust Act than his views on the Territorial

\footnotetext{
236 See supra note 5 and accompanying text. "LatCrit" stands for "Latina and Latino Critical Race Theory." See Francisco Valdes, Under Construction: LatCrit Consciousness, Community, and Theory, 85 CAL. L. REv. 1087, 1089 n.2 (1997) (undertaking the "difficult process" of defining LatCrit). For my personal take on the literature, see Pedro A. Malavet, Literature and the Arts as Antisubordination Praxis: LatCrit Theory and Cultural Production: The Confessions of an Accidental Crit, 33 U.C. DAvIs L. REv. 1293 (2000); Pedro A. Malavet, The Accidental Crit II: Culture and the Looking Glass of Exile, 78 Denv. U. L. REv. 753 (2001); and Pedro A. Malavet, The Accidental Crit III: The Unbearable Lightness of Being . . . Pedro, in PROFESSIONAL ForbearancE: NARRATIVES FROM MiNORITY LAW PROFESSORS ABOUT SURVIVING THE AMERICAN ACADEMY (Karla Erickson \& Angela Onwuachi Willig eds., forthcoming 2011).

237 PROCESSES OF CONSTITUTIONAL DECISIONMAKING: CASES AND MATERIALS 385-98 (Paul Brest et al. eds., 5th ed. 2006).

${ }_{238}$ Sanford Levinson, Installing the Insular Cases into the Canon of Constitutional Law, in Foreign IN A DOMESTIC SENSE: PUERTO RICO, AMERICAN EXPANSION, AND THE CONSTITUTION 121, 123 (Christina Duffy Burnett \& Burke Marshall eds., 2001) (noting that the Insular Cases were not extensively discussed in any of the "contemporary constitutional law casebooks or treatises"). See also Sanford Levinson, Why the Canon Should be Expanded to Include The Insular Cases and the Saga of American Expansionism, 17 CONST. COMMENT. 241, 241-66 (2000). Both works are referenced along with the continued dearth of coverage in A Convenient Constitution, supra note 5, at 985 \& n.31, 986 \& n.34, 1036 \& n.211, 1040 \& n.224, 1041 \& n.225.

239 See, e.g., The Story of Downes, supra note 1, RiCHARD DELGADO ET AL., supra note 5, at 52-64 (in the chapter on Puerto Rico and Puerto Ricans, note the section dedicated to Downes v. Bidwell and Balzac v. Porto Rico); RACE AND RACES, supra note 5 , at 359-69.
} 
Clause. ${ }^{240}$ The Fuller Court is often remembered in law schools for declaring the national income tax ${ }^{241}$ and a state law prohibiting more than sixty hours in a work-week unconstitutional. ${ }^{242}$ Its most famous case is Plessy v. Ferguson. Except for Joseph McKenna, who had been appointed by President McKinley to replace the retiring Justice Stephen J. Field, in January of $1898,{ }^{243}$ all the members of the Fuller Court when it decided Downes had been appointed prior to 1898 and were members of the Court that decided the notorious Plessy v. Ferguson in 1896; a decision in which Justice Brewer did not participate and Justice Harlan dissented. ${ }^{244}$ While the "separate but equal" standard of Plessy was relegated to the historical

240 'The 'rule of reason' became the standard for applying the Sherman Antitrust Act after the Court's opinions in Standard Oil Co. v. United States, 221 U.S. 1 (1911), and United States v. American Tobacco Co., 221 U.S. 106 (1911), both written by White." PrATT, supra note 165, at 6 n.24.

241 Pollock v. Farmer's Loan \& Trust Co., 158 U.S. 601 (1895). Reversed by the 16th Amendment.

242 Lochner v. New York, 198 U.S. 45, 53 (1905) (invalidating New York penal statute forbidding employers from requiring workers to exceed 60 hours in a work week). Cf. Muller v. Oregon 208 U.S. 412, 423 (1908) (upholding law restricting women working in laundries to no more than ten hours a day).

243 See 3 The JUSTICES OF THE UNITED STATES SUPREME CoURT 1789-1969: THEIR LIVES AND MAJOR OPINIONS 861 (Leon Friedman \& Fred L. Israel eds., Chelsea House Publishers 1969) [hereinafter 3 THE JUSTICES OF THE UNITED STATES SUPREME CoURT]. Field had been appointed to the Court by President Abraham Lincoln in 1863! See also 2 THE JUSTICES OF THE UNTTED STATES SUPREME COURT 1789-1969: THEIR LIVES AND MAJOR OPINIONS 534 (Leon Friedman \& Fred L. Israel eds., 1969).

244 Plessy v. Ferguson, 163 U.S. 537 (1896) (7-1 decision written by Brown; Harlan dissented). A law review article explains why Justice Brewer, who had joined the Court in 1890 , did not participate in the decision:

The final line of the United States Supreme Court opinion in the landmark case of Plessy v. Ferguson states, 'Mr. Justice Brewer did not hear the argument or participate in the decision of this case.' Because of the untimely death of his daughter, the 58-year old Justice had been forced to leave Washington, D.C. for his home in Leavenworth, Kansas, on April 13, 1896, the day Plessy was argued before the Court. Without Brewer, the Court voted 7 to 1 to uphold Louisiana's 'separate but equal' public accommodations law. Only Justice John Marshall Harlan, a former slaveholder from Kentucky, agreed that the challenged 'Jim Crow' statute violated the Fourteenth Amendment's guarantee of equal protection of the laws.

J. Gordon Hylton, The Judge Who Abstained in Plessy v. Ferguson: Justice David Brewer and the Problem of Race, 61 Miss. L.J. 315, 315-16 (1991). 
trash bin by Brown v. Board of Education, ${ }^{245}$ the Downes decision is still good law, as clearly stated in Boumediene.

By relieving Congress, the President and itself of most constitutional limitations on the exercise of their discretion, the Supreme Court in Downes intended to allow the government some flexibility in dealing with our new territorial possessions. That flexibility has now become a permanent system for the regulation of our island empire, rather than a transitional process, as it was for the Philippines and Cuba-Guantánamo and the Platt Amendment notwithstanding. The use of the cases by the Court in Boumediene changes nothing about that; rather, it reasserts the doctrine of the Insular Cases perhaps in even more dangerous form.

President George W. Bush's appointees to the Supreme Court, Chief Justice Roberts and Associate Justice Alito, sided with his administration in the dissents in Boumediene. ${ }^{246}$ Such loyalty from justices to the administration that appointed them is nothing new and it played an important role in the Insular Cases. As discussed above, the majority opinions in the cases resolved in 1901 were joined by Republican appointees who sided with a Republican President, and the dissents were issued principally by Democratic presidential appointees. ${ }^{247}$ The late Chief Justice William H. Rehnquist in his book The $S u$ preme Court ${ }^{248}$ discusses how President Theodore Roosevelt demanded to know how Oliver Wendell Holmes would vote on the Insular Cases before he would nominate him to replace the retiring Horace Gray on the Supreme Court. In a letter to Holmes' sponsor, Senator Henry Cabot Lodge, Roosevelt wrote:

The majority of the present Court who have, although without satisfactory unanimity, upheld the policies of Presi-

245 Brown v. Bd. of Educ., 347 U.S. 483 (1954).

246 Boumediene v. Bush, 553 U.S. 723, 801 (2008) (Roberts, C.J., dissenting, joined by Scalia, Thomas \& Alito, J.J.); Id. at 826 (Scalia, J., dissenting, joined by Roberts, C.J., Thomas \& Alito, J.J.). See also supra note 10 and accompanying text ("President George W. Bush nominated [Roberts] as Chief Justice of the United States, and he took his seat on September 29, 2005;" "President George W. Bush nominated [Alito] as an Associate Justice of the Supreme Court, and he took his seat on January 31, 2006.").

247 See supra note 165 and accompanying text.

248 WILLIAM H. REHNQUIST, THE SUPREME COURT 215-17 (2001). 
dent McKinley and the Republican party in Congress, have rendered a great service to mankind and to this nation. The minority-a minority so large as to lack but one vote of being a majority-have stood for such reactionary folly as would have hampered well-nigh hopelessly this people in doing efficient and honorable work for the national welfare, and for the welfare of the islands themselves, in Porto Rico and the Philippines. No doubt they have possessed excellent motives and without doubt they are men of excellent personal character; but this no more excuses them than the same conditions excused the various upright and honorable men who took part in the wicked folly of secession 1860 and 1861.

Now I should like to know that Judge Holmes was in entire sympathy with our views [on the Insular Cases] . . . 249

Rehnquist then concludes that "Holmes was duly appointed an associate justice [effective December $8,1902^{250}$ ], and largely fulfilled Roosevelt's expectations of him with respect to the so-called Insular Cases, which were a great issue at that time, although they are scarcely a footnote in a text on constitutional law today."251

As already discussed, the late Chief Justice is of course correct that Downes and the Insular Cases have been treated as a legal footnote for much of the past century. But they should not be. I had hoped that Boumediene would at least produce serious discussions of the decisions, but I am disappointed by the relatively small number of articles published after the decision that really address the issue. After all, Downes and the Insular Cases, as Teddy Roosevelt's litmus test for appointment of one of the best-remembered justices in history indicates, were critical decisions determining the kind of country that the United States was to become. Boumediene is easily understood as a decision that defines the country that we are today. But, Downes is also our living constitutional doctrine

\footnotetext{
249 Id. at 216.

2503 THE JUSTICES OF THE UNTED STATES SUPREME CoURT, supra note 243, at 878.

251 REHNQUIST, supra note 248 , at 217 . As was discussed in section VI above, Oliver Wendell Holmes acquiesced in the continued imposition of the White doctrine in the Insular Cases, but did not expressly embrace it; though if he disagreed he might have issued one of his now well-regarded dissents.
} 
and it daily affects the lives of millions of our citizens by creating an underclass of citizenship and United States territory in a permanent state of constitutional uncertainty about its future.

The "wartime" moments of 1898 and 2010 are more similar as far as the law is concerned than is generally realized. The Spanish-American War and the so-called War on Terror produced military engagements that involved a commitment of our armed forces and cost lives, innocent and not, on all sides of the conflicts. At the same time, the armed conflicts produced the need to make important decisions about how our Constitution should be applied to the emerging and perhaps unanticipated results of military victory and accompanying extended control over territory and people. On both occasions, the Supreme Court took a racialized "us vs. them" approach. That is, the Court believed that "grave questions will arise from differences of race, habits, laws and customs of the people, and from differences of soil, climate and production."252

While many will be seduced by the ruling's legitimate grant of habeas relief to the detainees, the articulated rationales underlying the Boumediene decision are deeply troubling. The Court reasserted a rule of plenary power over territorial citizens while barely acknowledging those citizens' existence and without recognizing the duration of the occupation of the current United States territories. The majority may have cast new doubt on the applicability of fundamental rights guaranteed by the Bill of Rights to the territorial citizens. Then, without any sense of irony, the Court discussed the Philippines and its "transition to independence," rearticulating in the process the doctrine of the Insular Cases as an old and well-established rule to be flexibly applied to temporary and transitional situations. The majority then placed what is currently happening in Guantánamo Bay in the category of these temporary situations.

The fallacy of those assumptions casts serious doubt on the soundness of Downes v. Bidwell and Boumediene v. Bush.

252 Boumediene v. Bush, 553 U.S. 723, 757 (2008) (citing Downes v. Bidwell, 182 U.S. 244, $282(1901))$. 
The Boumediene Court did not in any way recognize that over four million souls currently live under the rule of the Insular Cases and have done so for over a century. This means that the majority's reliance on the Insular Cases, and the dissenters' acceptance of their rule, are very inaccurately characterized in Boumediene. The only counter to such mischaracterizations of the cases is to go back to their original context-which this article has attempted to lay out only a very broad terms - and to acknowledge their continuous application for a period of over one hundred years to a particular group of current U.S. citizens.

Indeed, on the basis of this continuous relationship, Judge Gustavo Gelpí, of the United District Court for the District of Puerto Rico recently wrote:

Let it be clear. The court today is in no way attempting to overrule the Insular Cases as applied to the U.S. territoriesonly the Supreme Court can. The court, rather, today holds that in the particular case of Puerto Rico, a monumental constitutional evolution based on continued and repeated congressional annexation has taken place. Given the same, the territory has evolved from an unincorporated to an incorporated one. Congress today, thus, must afford Puerto Rico and the 4,000,000 United States citizens residing therein all constitutional guarantees. To hold otherwise, would amount to the court blindfolding itself to continue permitting Congress per secula seculorum to switch on and off the Constitution. [Citing Boumediene]. ${ }^{253}$

In the accompanying footnote Judge Gelpi clarifies that this is not a statement about statehood, but rather about incorporated territorial status, and that he bases his decision on Boumediene itself:

The issue of statehood for Puerto Rico is not before this court. As mentioned at the outset of this opinion ... the issue before the court pertains exclusively to civil rights and not status politics. May Congress, by allowing Puerto Rico to remain in

${ }^{253}$ Consejo de Salud v. Rullan, 2008 U.S. Dist. LEXIS 107905, ${ }^{\star 62} \&$ n.30 (D.P.R. Nov. 10, 2008). 
limbo between a mere territory and a state, indefinitely (versus "temporarily") preclude the Constitution from applying to the United States territory and citizens residing therein? Boumediene is clear that it may not. As Article IX of the Treaty of Paris recognizes, "civil rights" and "political conditions" are distinct concepts. ${ }^{254}$

Unfortunately, this particular opinion in an otherwise long litigation was never appealed ${ }^{255}$ and in April of this year the underlying complaint was voluntarily dismissed.256 Judge Gelpí's short-lived opinion is a step in the right direction because it challenges the fallacy that Puerto Rico's legal relationship to the United States is a "temporary" issue. But the matter remains in the hands of the Supreme Court and the United States Congress with the severe flaws and limitations that this article has sought to illuminate.

254 Id. at * 62 n.30

256 For a brief overview of this litigation see Concilio de Salud Integral de Loiza, Inc. v. Pérez-Perdomo, 551 F.3d 10 (1st Cir. 2008).

256 Consejo de Salud Playa de Ponce v. Sec'y of Health of P.R., 2010 U.S. Dist. LEXIS 37660 (D.P.R. Apr. 14, 2010). Judge Gelpi noted in his order that there had been a change in political administration in Puerto Rico following the elections of November 2008, after his original opinion on the Insular Cases was issued, and that the new administration had taken a different position on the constitutional matter. Id. at ${ }^{\star} 6 \mathrm{n} .1$. That said, in allowing the dismissal, he explained:

The parties, nonetheless, agree that the recent enactment of the American Recovery and Reinvestment Act of 2009, Public Law 111-5, 123 Stat. 115, and the Health Care and Education Reconciliation Act of 2010, Pub. L. 111-152 124 Stat. 1040, favorably alter the congressional treatment of the Commonwealth under the Medicaid Statute. In light of said changed scenario, the Commonwealth, in particular, understands that "it is not in the best interest of its constituents to further pursue the constitutional challenges under such circumstances". 
